This study is the outcome of collaborative research between the Secretariat of the World Trade Organization (WTO) and the International Labour Office (ILO). It addresses an issue that is of concern to both organizations: the relationship between trade and employment.

On the basis of an overview of the existing academic literature, the study provides an impartial view of what can be said, and with what degree of confidence, on the relationship between trade and employment, an often contentious issue of public debate. Its focus is on the connections between trade policies, and labour and social policies and it will be useful for all those who are interested in this debate: academics and policy-makers, workers and employers, trade and labour specialists.
WTO ISBN $\quad 978-92-870-3380-2$ ILO ISBN 978-92-2-119551-1
A joint study of the International Labour Office and the Secretariat of the World Trade Organization 



\section{TRADE AND EMPLOYMENT}

\section{CHALLENGES FOR POLICY RESEARCH}

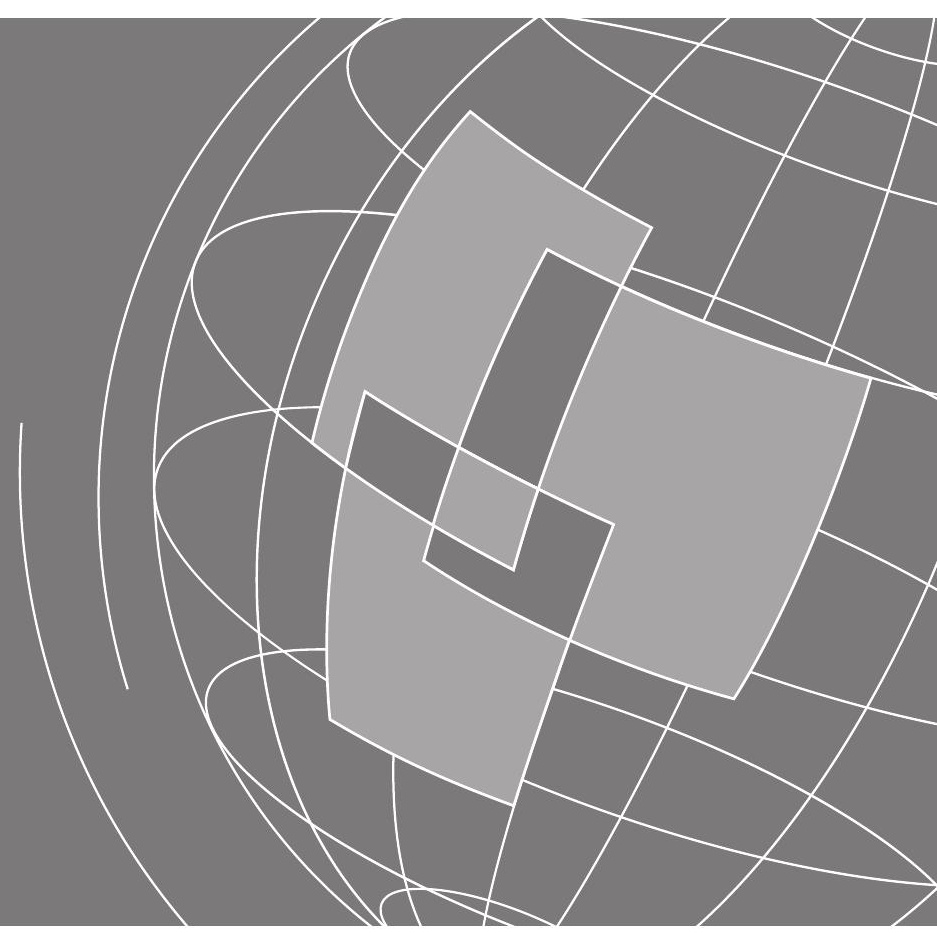

A joint study of the International Labour Office and the Secretariat of the World Trade Organization

Prepared by

Marion Jansen

Economic Research and Statistics Division World Trade Organization
Eddy Lee

International Institute for Labour Studies International Labour Office

International Labour Office - Geneva 
Copyright $\odot 2007$ International Labour Organization and World Trade Organization.

Publications of the International Labour Office and World Trade Organization enjoy copyright under Protocol 2 of the Universal Copyright Convention. Nevertheless, short excerpts from them may be reproduced without authorization, on condition that the source is indicated. For rights of reproduction or translation, application should be made to the WTO Publications, World Trade Organization, CH-1211 Geneva, Switzerland, or by email: publications@wto.org. The International Labour Office and World Trade Organization welcome such applications.

The designations employed in ILO and WTO publications, which are in conformity with United Nations practice, and the presentation of material therein do not imply the expression of any opinion whatsoever on the part of the International Labour Office or the World Trade Organization concerning the legal status of any country, area or territory or of its authorities, or concerning the delimitation of its frontiers.

The responsibility for opinions expressed in studies and other contributions rests solely with their authors, and publication does not constitute an endorsement by the International Labour Office of the World Trade Organization of the opinions expressed in them.

Reference to names of firms and commercial products and processes does not imply their endorsement by the International Labour Office or the World Trade Organization, and any failure to mention a particular firm, commercial product or process is not a sign of disapproval.

WTO ISBN 978-92-870-3380-2

ILO ISBN 978-92-2-119551-1

Also available in French and Spanish:

French title ILO ISBN 978-92-2-219551-0 / WTO ISBN 978-92-870-3381-9

Spanish title ILO ISBN 978-92-2-319551-9/ WTO ISBN 978-92-870-3382-6

ILO and WTO publications can be obtained through major booksellers or:

- ILO local offices in many countries, or direct from ILO Publications, International Labour Office, CH-1211 Geneva 22, Switzerland. Catalogues or lists of new publications are available free of charge from the above address, or by email: pubvente@ilo.org. - ILO website: www.ilo.org/publns

- direct from WTO Publications, World Trade Organization, 154, rue de Lausanne, CH1211 Geneva 21,Tel: (41 22) 73952 08, Fax:(41 22) 73954 58,Email: publications@wto.org. - online WTO bookshop : http://onlinebookshop.wto.org

Printed by WTO Secretariat, Switzerland, 2007 


\section{ACKNOWLEDGEMENTS}

The authors thank Hilda Addison and Monica Takyi-Appiah for research assistance and Peter Auer, Duncan Campbell, Michael Finger, Ajit Ghose, Rizwanul Islam, Arne Klau, David Kucera, Karen McCusker, José Manuel Salazar-Xirinachs, Ritash Sarna and Rolph Van der Hoeven for comments on earlier versions of this study. Any remaining errors are the fault of the authors. 


\section{FOREWORD}

This study is the outcome of collaborative research between the Secretariat of the World Trade Organization (WTO) and the International Labour Office (ILO). It addresses an issue that is of important concern to both organizations, that is, the relationship between trade and employment.

The multilateral trading system has the potential to contribute to increasing global welfare and to promote better employment outcomes. The challenge all our Members face is to find ways of realizing this potential as fully as possible. A first step in that direction is to improve our understanding of how trade and labour markets interact and affect the lives of millions around the world.

We consider this joint study undertaken by the ILO and the Secretariat of the WTO a useful and timely initiative that will promote greater understanding and assist governments in making decisions in an increasingly complex and fast-changing environment. In joining the expertise of the two Secretariats, this technical study aims to provide a broad and impartial view of what can be said - and with what degree of confidence - about the relationship between trade and employment, and the way in which trade policies and labour market policies affect this relationship. The study also identifies questions that are not always well understood in the literature, and on which more research would be useful.

We are therefore pleased to present this study as an encouraging illustration of how useful collaboration can be developed between the two Secretariats on issues of common interest. 
A. INTRODUCTION

B. TRADE FLOWS AND EMPLOYMENT:

THE CURRENT CONTEXT

1. Trade and income levels

2. Trade, job destruction, job creation and unemployment: what theory tells us

3. The evidence: trade and (un)employment 30

D. TRADE AND INEQUALITY 38

1. Trade and inequality: what theory tells us 40

(a) Trade and the relative demand for different types of labour

(b) Trade, FDI and the possibility to substitute domestic workers by foreign workers.

2. The evidence: trade and wage inequality 45

3. The evidence: trade and income inequality 50

4. The evidence: trade, FDI and the possibility to substitute domestic workers by foreign workers

(a) Does globalization affect labour demand elasticities? 
(b) Globalization, insecurity and the bargaining power of workers

(a) Insuring workers against adverse professional events

(b) Facilitating transition following trade reform 60

(i) Social protection and the potential role of the international community.

(ii) Active labour market policies 63

(c) Freedom of association and collective bargaining 65

(d) Trade reform and the informal economy in developing countries

(a) Supply response in developing countries 80

(b) The role of financial markets for efficiency and stability

(c) The pace of trade liberalization 


\section{TRADE AND EMPLOYMENT} CHALLENGES FOR POLICY RESEARCH

A joint study of the International Labour Office

and the Secretariat of the World Trade Organization

\section{EXECUTIVE SUMMARY}

\section{Objective}

This study is the product of a collaborative effort by the Secretariat of the World Trade Organization (WTO) and the International Labour Office (ILO), aimed at providing an impartial view of what can be said, and with what degree of confidence, on the relationship between trade and employment, an often contentious issue of public debate. It attempts to do this through a review of the academic literature, both theoretical and empirical. A huge amount of research has been undertaken on this subject and within this there are numerous excellent literature surveys. This study intends to distinguish itself from the existing surveys by focusing on the connections between trade policies, and labour and social policies.

\section{Basic issues}

Economists have long recognized that trade would lead to a division of labour advantageous to everybody involved. Indeed, by reshuffling resources in accordance with the principles of comparative advantage, they can be used more appropriately and effectively for production, thus creating the so-called gains from trade. Highly productive producers will be able to expand as they start selling their goods or services abroad. Producers and consumers will be able to 
take advantage of cheaper imports and of a larger product and quality choice. The latter, however, implies that some domestic production will be replaced by imports.

In other words, trade liberalization is expected to trigger a restructuring of economic activity that takes the form of company closures and job losses in some parts of the economy and startups of new firms, investment in increased production and vacancy announcements in other parts of the economy. Trade liberalization is therefore associated with both job destruction and job creation. In the short run the resulting net employment effects may be positive or negative depending on country specific factors such as the functioning of the labour and product markets. In the long run, however, the efficiency gains caused by trade liberalization are expected to lead to positive overall employment effects, in terms of quantity of jobs, wages earned or a combination of both. Average wage increases may, however, hide distributional changes that affect some workers negatively.

Where trade liberalization affects parts of the labour force negatively, labour and social policies are required in order to redistribute some of the gains from trade from winners to losers. This study tries to identify situations in which such government intervention may be helpful, and individuals and groups that should be targeted. It also discusses the possible effects of different types of labour and social policies in the relevant situations. In this discussion it is pointed out that labour and social policies may have unintended efficiency effects. Indeed, to the extent that such policies may have a negative effect on the above-mentioned "reshuffling" process that is necessary in order to reap the benefits from trade, policy-makers may be confronted with a trade-off, although not necessarily a very steep one. 


\section{Recent developments}

Traditionally, economists expected that the reshuffling process triggered by trade liberalization would take place across sectors. Roughly speaking, it was expected that labour-intensive industries would shrink in developed countries, while skill and/or capital intensive industries would expand. The opposite phenomenon was expected to happen in developing countries. In developed countries jobs would therefore be destroyed in labour-intensive industries and capital employed in those industries would have to be re-employed. The long-run distributional consequences of trade would imply increased inequality between capital and labour or between skilled and unskilled labour in the developed world. In contrast, inequality was expected to decrease in the developing world.

Empirical evidence initially appeared to confirm these predictions. In particular, decreases in inequality were observed in a number of East Asian economies that liberalized trade. At the same time, increases in the wage differential between high-skilled and lowskilled labour - the so-called skill premium - were observed in a number of developed countries. In other developed countries where labour market policies, such as minimum wages, limited the extent of wage adjustments, increases in low-skilled unemployment were observed.

But three important phenomena emerged that were not in line with traditional trade theory, and a large body of theoretical and empirical literature has tried to respond to this discrepancy between traditional predictions and observed realities.

1. First, most industrialized countries trade above all with other industrialized countries. Traditional trade theory was only of very limited use in predicting employment effects resulting from this type 
of trade. Recent contributions to the theoretical trade literature have therefore looked at the question of whether trade among similar countries, i.e. intra-industry trade, may have an impact on the demand for high-skilled and low-skilled labour and some of these studies have combined trade with technological change. This literature comes to the conclusion that trade among similar countries can raise wage inequality within countries and also within sectors.

Another branch of literature has examined the relationship between openness and the sensitivity of labour demand to wage changes. In this context it has been argued that in an open economy employers would be more likely to threaten to lay off workers when they demand higher wages than in a closed economy, for instance, because they face stiffer price competition than before. Economists refer to this increased sensitiveness as an increase in the price elasticity of labour demand. This line of argumentation has two important implications. First, trade between industrialized and developing countries will affect the elasticity of labour, but the same is true for trade among industrialized countries. Second, the price elasticity of demand can be affected by the mere possibility of trade. For instance, the mere threat of sourcing inputs from another country or of delocalization may weaken workers' resistance to wage reductions.

This literature may explain why surveys in industrialized countries have revealed that workers in very different types of industries report greater perceived job insecurity as countries liberalize. The theoretical literature confirms that trade, in particular if combined with Foreign Direct Investment (FDI), has the potential to increase volatility in labour markets. Surprisingly, though, statistics on labour market reallocation do not reveal a systematic pattern of increased labour 
market volatility. Work on how to reconcile the conflicting evidence on workers' perceptions of insecurity on the one hand, and labour market statistics on the other, is ongoing in the research community.

2. Second, in contrast to expectations, increases in the skill premium were also observed in developing economies during periods of trade liberalization, notably in a number of Latin-American economies. A large body of empirical literature has tried to explain this phenomenon and finds that the timing of trade liberalization, the tariff schedules in place before liberalization, and technological change are some of the elements that explain why certain developing countries have experienced increases in the skill premium after trade liberalization. The relevant theoretical literature has focused on the interaction between trade, FDI and technological change in order to explain changes in wage inequality in developing countries. The increasing importance of FDI has also led to renewed interest in the functional distribution of income between capital and labour - as opposed to the ratio between wages of high-skilled and low-skilled workers - and in income inequality more generally.

3. Third, a lot of employment reshuffling was observed to take place within sectors rather than across sectors as traditional trade theory would predict. In response, a new generation of trade models was developed that describes mechanisms according to which trade liberalization encourages the expansion of the most productive suppliers in all sectors, i.e. in sectors in which countries are net exporters and in sectors in which they are net importers. As a result, these models predict that in all sectors jobs are created by those suppliers who are able to compete at the international level and destroyed by those suppliers who are unable to compete. For policymakers this may be good news, as it is generally expected that it is 
easier for workers to change firms within the same sector than to find work in a different sector. Within-sector reallocation may, for instance, imply lower retraining costs for workers and shorter search periods. On the other hand, these new trade models imply that jobs are at risk in all sectors. While traditional trade models would suggest that policymakers who wish to assist workers should focus on import-competing sectors, more recent research suggests that such targeted intervention is not justified. Indeed, recent literature emphasizes that it will be increasingly difficult for policy-makers to predict which will be the jobs at risk and which will be the jobs in demand in the near future.

A rich empirical literature has emerged from the analysis of these different phenomena. One major difficulty that empirical studies on the impact of trade on employment face is in distinguishing the different possible causes of employment changes. Some of these causes have a global character, like technological change, others are country specific. Labour market policies, macroeconomic policies or movements along the business cycle are only a few examples of country specific factors that may affect an economy's employment level and structure. They may also affect the reaction of the labour market to changes in trade policy. Not surprisingly, therefore, one of the general conclusions that can be drawn from the literature is that the employment effects of trade have differed significantly across countries.

\section{Implications for policy design}

The present study goes on to discuss a number of policies from three different angles: their potential to affect the link between trade, growth and employment either positively or negatively, their effect on redistribution, and their potential to provide security and insurance against major adverse events in working life. 
- Policies facilitating the transition following trade reform

Workers who lose their job following trade reform have to look for a new job and potentially have to go through a period of unemployment. They may be expected to relocate or to undergo retraining. Two types of labour market policies targeting this situation can be distinguished: passive income support during periods of unemployment and so-called active labour market policies that attempt to facilitate re-employment.

Most industrialized countries have more or less generous social protection systems in place, but this is not the case in many low and middle income countries. Active labour market policies are widely used in industrialized countries where they are increasingly being seen as a preferable alternative to passive income support for the unemployed. Some industrialized countries even provide specific trade adjustment assistance to workers.

The possibility of introducing social protection or active labour market programmes of limited duration, and specifically targeting those negatively affected by trade reform, has been discussed in the literature and has recently been raised in the context of the debate on aid for trade. Strengthening the capacity of developing countries to design and implement such programmes could, indeed, enable them to cope better with the social impact of economic reforms as well as help to increase popular support for the reforms themselves. There is, however, room for more research in order to improve our understanding of how to design such programmes. 
- Policies to provide security and insurance against adverse events

The policies for facilitating transition discussed above are part of the general problem of providing security and insurance against adverse events. Economists tend to agree that modern economies need to constantly reallocate resources, including labour, from old to new products, from inefficient to efficient firms. At the same time, workers value security and insurance against major adverse professional events, job loss in particular. In response to this demand for insurance, economies have used different tools, like unemployment benefits and job security legislation, to provide a buffer against the most negative consequences of job loss. The discussion in this study shows that there are reasons to believe that a trade-off exists between efficiency and insurance, but that this trade-off does not need to be very steep if insurance policies are designed appropriately. Getting the policy mix right is a pressing issue. This is above all the case in developing countries that face the additional challenge of channelling important numbers of workers from the agricultural sector and the urban informal economy as smoothly as possible into formal activities.

\section{- Redistribution policies}

It is also increasingly recognized that it is important for policymakers to ensure that the benefits of global economic integration are sufficiently widely shared in order to maintain or obtain public support for trade opening. This study provides a discussion of the literature on redistribution policies in open economies and finds that there is so far no agreement on how to design appropriate redistribution policies in a globalizing world. The difficulty in designing an effective redistribution policy arises from the fact that such policies are likely to affect not only the distribution of income but also incentives in the productive system. Redistributive transfer may affect the incentives 
faced by those who receive them as well by those who pay for them through, for instance, income or consumption taxes. An additional complication may arise if the ability of governments to redistribute is affected by the fact that some production factors are more mobile at the global level than others.

Independent of their causes, increases in the skill premium or income inequality represent a particularly serious challenge for developing countries with limited experience in the design of redistribution policies. The literature does not so far provide an answer to the question of how to introduce appropriate policies in countries that lack the necessary administrative and financial capacities.

\section{- Education policies}

Policies that provide wider access to education have been identified in the literature as good pro-poor policies, as they stimulate growth and reduce inequality at the same time. The present study also emphasizes the increasingly important role of education policies in determining how well countries cope with economic and technological change. Education levels, for instance, determine countries' absorptive capacity, i.e. their capacity to adopt new technologies and maybe develop them further. Education affects individuals' capacity to deal with change, an important aspect in a globalized world that expects individuals to adapt constantly to new situations. At the same time this study points out that it becomes increasingly hard to predict the set of skills needed for future employment and that education systems will therefore need to be increasingly flexible in order to respond to economic changes. The practical implications of this, however, do not appear to be entirely clear and further research on the issue of economic change and education could be useful to provide guidance to those responsible for education policy. 


\section{- Other policies}

How successful developing economies are in the creation of more and/or better jobs, with attendant implications for poverty, depends above all on the supply response of the economy to trade liberalization. There appears to be a common understanding of the possible bottlenecks for supply response in developing countries. They include inadequate finance, physical infrastructure, telecommunication, information and human capital. It has also been argued that the pace of trade reform may affect countries' supply response. There appears to be an increasing awareness of the role the international community can play in helping developing countries to overcome supply constraints, that is reflected in the debate on aid for trade. In this context it could be useful to improve our understanding of how to effectively use aid for trade in order to optimize developing countries' supply response.

\section{Main conclusion}

The single main conclusion that emerges from this study is that trade policies and labour and social policies do interact and that greater policy coherence in the two domains can help to ensure that trade reforms have significantly positive effects on both growth and employment. From this perspective, research directed at supporting the formulation of more effective and coherent policies would clearly have a high pay-off to the international community. 


\section{TRADE AND EMPLOYMENT CHALLENGES FOR POLICY RESEARCH}

A joint study of the International Labour Office and the Secretariat of the World Trade Organization 



\section{TRADE AND EMPLOYMENT CHALLENGES FOR POLICY RESEARCH}

\section{A. INTRODUCTION}

The growing role of trade and foreign direct investment (FDI) flows in the global economy has generated increasing interest among policy-makers, the media and the general public in its impact on employment and incomes across the world. In mainstream economic theory it is presumed that these developments will, in spite of possible problems of adjustment inherent in the process, eventually yield net benefits in terms of employment and incomes in the global economy. In contrast, discussions of the issue in the media often focus on negative effects such as job losses resulting from increased import competition and the displacement of local firms by FDI; the relocation of jobs from high to low-wage economies, and claims that increasing globalization has triggered a "race to the bottom" in terms of wages and the quality of employment.

This study is the result of a collaborative effort by the ILO and the Secretariat of the WTO and aims at providing an impartial view of what can be said, and with what degree of confidence, on the relationship between trade and employment. It attempts to do this through an objective review of the academic literature, both theoretical and empirical. A large amount of research has been undertaken on this subject and within this there are numerous excellent literature surveys. ${ }^{1}$ This study intends to distinguish itself from these existing

\footnotetext{
1 Surveys include Cline (1997), Slaughter (1998), Gaston and Nelson (2001), Acemoglu (2002), Ghose (2003), Feenstra and Hanson (2004), Goldberg and Pavcnik (2004) and Hoekman and Winters (2005).
} 
surveys by its focus on the link between trade policies on the one hand, and labour and social policies on the other hand.

Trade policies have a significant impact on the level and structure of employment, on wages and wage differentials, and on labour market institutions and policies. At the same time, labour and social policies influence the outcomes of trade policies in terms of the growth of output and employment and the distribution of income. There appears to be a need to disentangle the range of quite complex relationships that exist between trade policy, growth, employment, job quality, wages, poverty, inequality, and adjustment policies. This could serve as a useful input to the policy-making process in both domains. It may also act as a stimulus towards greater policy coherence that may ultimately contribute to increasing the economic and social benefits of trade liberalization and expansion.

\section{B. TRADE FLOWS AND EMPLOYMENT: THE CURRENT CONTEXT}

Trade has played an increasing role in the world economy over the past decades as illustrated by the fact that the growth of real trade exceeded that of world output. The ratio of world exports of goods and services to GDP rose from 13.5 per cent in 1970 to 32 per cent in 2005 and all major geographic regions recorded an excess of trade over output growth.

However, global trade expansion experienced several temporary setbacks over these three decades, most notably during the Asian financial crisis (1996-98) and the recession in the aftermath of the burst of the information technology bubble in 2001. Nevertheless, global trade expansion over the last decade (1995-2005) was nearly six per cent per annum, almost two times stronger than global GDP growth. 
The driving forces in this trade expansion over the last decades include the deepening of the regional integration of Europe (European Union) and North America (NAFTA), the shift to more outward oriented trade policies in several large emerging markets (e.g. China and Mexico) combined with unilateral liberalization measures in many other developing countries and the multilateral liberalization in the Uruguay Round. ${ }^{2}$ Other motors of the global trade expansion were the dynamic growth of the information and telecommunication sector and the rise in FDI flows since 1980.

FDI flows started to rise strongly from the first half of the 1980 s onward. Particularly buoyant FDI inflows were recorded into China but other emerging markets in, for instance, East Asia and MERCOSUR also attracted large FDI inflows. While in the early 1980s global annual FDI flows hovered at around $\$ 55$ billion they reached $\$ 200$ billion in 1990-94 and after rising steadily peaked at $\$ 1300$ billion in 2000 under the impact of a merger and acquisition frenzy and high price stock valuations. By 2003 global FDI flows contracted by half but recovered partially in 2004 and 2005 when the flows again reached a level of $\$ 900$ billion. ${ }^{3}$ The contribution of FDI to trade growth is particularly evident in the case of China where foreign-invested enterprises account for more than half of its merchandise exports.

According to estimates of the WTO Secretariat, ${ }^{4}$ the value of world merchandise exports rose by 13 per cent and reached $\$ 10.2$ trillion in 2005 thereby exceeding slightly the rise in the value of world services exports. ${ }^{5}$ The major features of global trade developments in 2005

\footnotetext{
2 One of the Uruguay Round's achievements was that the share of duty free lines in developed countries' imports of industrial products rose from 20 to 43 per cent.

3 These values refer to averages of FDI in- and outflows (UNCTAD, 2005 and UNCTAD, 2006a).

4 WTO (2006).

5 The value of services exports amounted to $\$ 2.4$ trillion in 2005 reflecting an increase of 10 per cent.
} 
included the marked rise in oil and other commodity prices, which benefited the exporters of primary commodities, and the continued outstanding trade growth of China in manufactured goods and of India in services trade. The combination of these three phenomena has lifted the share of the developing countries in world merchandise trade to 34 per cent, a new record level in the post WWII period. The emergence of China as the third largest merchandise trader, with a large trade surplus in manufactured goods, and the dynamic growth of India's software exports over the last five years has raised anxieties in many parts of the world that, as China becomes the factory and India the office for the world economy, the other regions would suffer from a lack of employment growth.

In order to place these anxieties in perspective it will be useful to recall a few basic facts on the global employment situation. The global labour force in 2005 numbered 2.8 billion, of which 0.55 billion were in $\mathrm{OECD}$ countries. Although trade and FDI are playing an increasing role in the global economy, most jobs in the world have yet to be directly affected by these developments. This is true of both industrialized and developing countries. In the former, over 70 per cent of total employment is in the service sector and, in spite of the recent growth in trade in services, most of this sector consists of non-tradable activity. In the latter, especially in low-income countries, the bulk of employment is still in subsistence agriculture and the informal economy, both of which are also, for the most part, non-tradable activities. For the majority of the world's working population it is, therefore, still the level of development and the performance of the domestic economies in which they work that determine their job and income prospects.

Viewed as a whole, there have also been few dramatic shifts in the global employment situation, certainly neither a dramatic 
improvement nor deterioration over the past two decades. In the OECD countries the levels of unemployment increased significantly in the 1970s and remained high for the next two decades. Since 1994, however, "labour market performance in the OECD area as a whole has improved; the unemployment rate has come down, the employment rate has gone up and the participation rate has risen" (OECD, 2005). A similarly reliable assessment for developing countries as a whole is difficult to arrive at because of the lack of data but the estimates that have been made in spite of this difficulty do not show a dramatic change. The ILO's Global Employment Trends (2006) shows slight increases in the unemployment rates in most developing regions and a slight decline in the Middle East and North Africa over the past decade. There has also been little change in the overall levels of underemployment and in the proportion of the working poor in total employment.

Over the same period, however, there has been a significant reduction in poverty and hence the proportion of working poor, in China and, to a lesser extent, in India. This implies that there has been a significant deterioration in the working poor and poverty situation in other parts of the developing world, especially in subSaharan Africa. This latter fact has given rise to several concerns over the adequacy of employment growth in the global economy. A major concern relates to the fact that many developing countries have yet to share in the benefits of globalization in terms of higher rates of growth of output and employment (WCSDG, 2004). A related concern is that relatively stable unemployment and underemployment rates may simply be masking the fact that there has been a deterioration in the quality of employment. The argument is that while overall job creation may be adequate, most new jobs have consisted of low quality employment, for instance, in the informal economy. There is 
consequently a growing recognition that it is important to find ways of increasing the pace at which good jobs are being created in the global economy. ${ }^{6}$

Turning to the structure of global employment, this has continued to shift but only gradually. The share of global employment in agriculture has continued to fall. Nevertheless, in 2005 it still accounted for 40 per cent of total employment, most of which is in the developing countries. The share of industrial employment has remained constant at 21 per cent; however given the growth in total employment over the period, this represented an additional 95 million jobs in the industrial sector, most of which were created in developing countries. The share of employment in services increased throughout the world. This is a continuation of a long-standing trend in the industrialized countries. In the developing countries this is partly a reflection of the continued growth of employment in the informal economy.

This aggregate picture of gradual change is not, however, inconsistent with the fact that there have indeed been countries and economic sectors that have experienced intense change in employment conditions as a result of globalization. The limited change in the aggregate employment picture is nonetheless a useful reminder that the scale of these changes has been small in relation to the whole. This is a reflection of the fact that the growth of trade and investment flows has so far been highly concentrated, in terms of a North-South divide as well as, within the South, in a small number of developing countries. Nevertheless, in spite of this pattern of concentration, the size of the impact of trade and investment flows on

\footnotetext{
6 These considerations have led to calls for greater priority to be given to the goal of full and productive employment and decent work in both international and national policies. The most recent example of this is the ECOSOC Ministerial Declaration in July 2006 on "Creating an environment at the national and international levels conducive to generating full and productive employment and decent work for all, and its impact on sustainable development"(www.un.org/docs/ecosoc).
} 
employment in the global economy is likely to increase significantly since the group of globalizing countries from the South now includes China and India, the two most populous countries in the world. Both have experienced very rapid growth as well as increasing integration into the global economy.

\section{TRADE AND EMPLOYMENT: THEORY AND EVIDENCE}

Trade expands because individuals and companies around the globe increasingly resort to importing and exporting goods and services, presumably because they find it advantageous. Adam Smith made reference to the propensity in human nature to "truck, barter, and exchange one thing for another" that would lead to a division of labour advantageous to everybody involved. Indeed, by reshuffling resources in accordance with the principles of comparative advantage, they can be used more appropriately and effectively for production. The result is increased efficiency, reflected in lower prices of inputs and final goods. In addition, consumers and producers benefit from a larger choice of products and quality. For all these reasons, market opening is expected to boost national incomes and possibly economic growth.

The "reshuffling" of production factors necessary to exploit comparative advantage can in real life take the form of company closures and job losses in some parts of the economy, with startups of new firms, investment in increased production and vacancy announcements in other parts of the economy. Trade liberalization is therefore associated with both job destruction and job creation. Whether the resulting net employment effects are positive or negative in the short run mainly depends on country specific factors like the functioning of the labour market. In the long run, however, the efficiency gains caused by trade liberalization are expected to lead to 
positive employment effects, either in terms of quantity or quality of jobs or a combination of both.

The theoretical literature provides interesting insights into the process of job destruction and job creation following trade liberalization and illustrates how different country characteristics, including labour market policies, can affect temporary and permanent employment effects at the sectoral or country level. Due to a combination of methodological and data problems, it has been more difficult to provide robust empirical evidence for the relative impact of trade liberalization and other domestic policies on employment changes and economic growth. The empirical literature on trade and the quality of employment, for instance, has focused on the income effects of trade. Although there is broad agreement that the quality of employment involves other aspects, like safety conditions in the workplace or job stability, no appropriate data exist so far that would allow economists to provide a systematic analysis of changes in job quality according to this broader concept.

\section{Trade and income levels}

With respect to income, the theoretical literature mentioned before predicts that trade liberalization raises average income levels, and some contributions to the theoretical growth literature suggest that trade also stimulates growth. A large number of multi-country case studies and econometric studies using cross-country datasets have tested the empirical validity of this trade-growth relationship but so far there is no full agreement among economists concerning the precise nature of this relationship.?

\footnotetext{
7 See Baldwin (2003) for an overview of the openness and growth debate. Main contributions to this literature are Dollar (1992), Harrison (1996), Rodriguez and Rodrik (2001) and Sachs and Warner (1995) and more recently: Dollar and Kraay (2004), Loayaza, Fajnzylber and Calderón (2005) and Wacziarg and Welch (2003).
} 
There are several reasons for this continuing disagreement. Differences in the quality and detail of data being analysed are one source of disagreement among economists. In particular, in developing countries the lack of good data often makes it necessary to have recourse to case studies. While many insights have been revealed from such studies, some are reluctant to draw broad generalizations from them because of their specificity and the bias that the personal viewpoint of the authors may introduce in such studies. ${ }^{8}$ Another source of disagreement is that some econometric studies analyse the impact of trade on growth, while others emphasize instead the need to focus on the impact of trade policies. Focusing on "openness", typically measured as the ratio between exports and/or imports on the one hand and GDP on the other hand, ignores the fact that the reduction of trade barriers does not necessarily lead to more trade. Indeed, a disappointing supply response to policy reform has been observed in numerous developing countries and lies at the origin of the recent debate on aid for trade. ${ }^{9}$ Another problem with the use of this measure is that countries whose incomes are high for reasons not related to trade, may well be characterized by a high trade share. If this is the case, the finding of a positive relationship between trade shares and income per person using standard econometric approaches does not allow for the conclusion that trade has a positive effect on growth. ${ }^{10}$

Notwithstanding the discussed data and methodological problems encountered by those analysing the relationship between trade and average income, and notwithstanding the persistent disagreement on the importance of this relationship, there appears to be agreement that,

8 Baldwin (2003).

9 See also UNCTAD (2006b) and the discussion in section E.4.a of this study.

10 Such econometric work would suffer from a so-called endogeneity problem. See Lee et al. (2004) for a recent paper that attempts to control for the effect of growth on openness. The results of this paper suggest that openness has a positive effect on growth, although a small one. This result stands, despite the equally robust effect of growth on openness. 
on balance, general economic openness is much more favourable to growth than a general inward-looking economic approach. Significant uncertainty, however, exists in the profession as to the exact policy mix which can maximize the growth effects of trade reform at a certain time and under certain circumstances.

Another strand of literature that gives insights into the income effects of trade reform is the so-called Computable General Equilibrium (CGE) literature. CGE models are computer-based simulations, like laboratory experiments, that show what today's economy will look like in the future as the result of a specified set of policy changes. Different simulations have generated widely varying predictions as to the dimensions of the economic gains for different trade liberalization scenarios." One interesting exercise that has been performed with this tool is the analysis of the geographical distribution of economic gains, although again with differing outcomes. Some studies, for instance, predict that agricultural liberalization in the context of the Doha Round will lead to losses in sub-Saharan Africa, while other studies predict gains for the region. ${ }^{12}$

In general, both strands of empirical literature analysing the trade and income relationship have one major shortcoming that is of relevance for this study: they look at overall or average income gains for the economy and do not look at the effects of trade on subgroups within the economy. In particular, the results of this literature do not automatically allow for conclusions as to the effect of trade on the average income of workers (as opposed to capital-owners, for instance), of the poor or of the median family in the economy.

11 See Piermartini and Teh (2005) for an overview.

12 See Anderson and Martin (2006), Bouët et al. (2005), Decreux and Fontagné (2006) and Polaski (2006). 
There are two exceptions to this general rule in the CGE literature. Polaski (2006) uses a setup that allows for the analysis of the returns to certain production factors and finds, for instance, that returns to agricultural labour would increase in most developing countries as the result of the so-called Hong Kong Scenario for trade liberalization, while the model's assumptions would lead to largely unchanged wages for unskilled labour. ${ }^{13}$ The study by Anderson and Martin (2005) provides explicit results for changes in the incidence of poverty and predicts a reduction in poverty resulting from more or less ambitious liberalization scenarios in the Doha Round.

A small number of cross-country econometric studies also provide insights into the income effects of trade reform for subgroups in the population. The study by Rama (2003) explicitly looks at the effects of trade reform on wages and finds that wages grow faster in economies that integrate with the rest of the world. The author concedes that openness to trade can have a negative impact on wages in the short run, but finds that it only takes a few years for this effect to change sign. The impact of foreign direct investment is highly positive even in the short run, highlighting the importance of a good investment climate. Also Lopez (2004) differentiates between the short and longrun impact of different policies, including the impact of open trade regimes. He finds that trade openness raises inequality and stimulates growth at the same time; he therefore refers to trade liberalization as a win-lose policy. Improvements in infrastructure and in education on the other hand reduce inequality and increase growth at the same time; so does inflation reduction.

The empirical work by Dew-Becker and Gordon (2005) has drawn the attention of policy-makers to the fact that the evolution

13 The study assumes an abundant supply of unskilled labour in the developing world. 
of average income can deviate significantly from the evolution of median income. In particular, they find that in the United States over the entire period 1966-2001, as well as over 1997-2001, only the top 10 per cent of the income distribution enjoyed a growth rate of real wage and salary income equal to or above the average rate of economy-wide productivity growth. This finding suggests that the income distribution in the United States is becoming increasingly unequal, an issue that will be discussed in more detail in section $D$ of this study. Suffice to say that changes to income distribution are likely to become a significant matter of concern for policy-makers if they negatively affect the incomes of median families, i.e. those families that can be determinant for election outcomes.

\section{Trade, job destruction, job creation and unemployment: what theory tells us}

Traditional trade models assumed that countries' technological capacities and/or relative endowments with production factors like capital, land, skilled and unskilled labour would determine the competitiveness of different sectors at the global level. As a consequence each country would have a set of identifiable exporting sectors and import-competing sectors. Exporting sectors would expand production and their demand for labour, while importcompeting sectors would reduce production and possibly lay off workers. But traditional trade models were not concerned with the reshuffling process itself, i.e. the loss of jobs and the process involved in finding a new one. It was assumed that all workers were employed before trade liberalization and that adjustment to the reform would 
take place instantaneously. ${ }^{14}$ Given this assumption that laid-off workers would automatically move into new jobs, the issue of traderelated unemployment did not arise.

However, this assumption of full employment did not imply that there were no other effects of trade liberalization on workers. Although it did not affect the quantity of jobs, trade liberalization affected the quality of jobs. Since it was assumed that exporting and import-competing sectors employ different types of workers or employ them in different proportions, trade liberalization would in the long run affect the relative demand for different types of workers; and this change in relative demand would result in relative income changes. In other words, traditional trade models would not allow for the conclusion that trade affects the level of employment or unemployment. They would rather lead us to expect that some workers may be better or worse off in the long run because of changes in their wages. In particular, economists predicted that trade between industrialized and developing countries would lead to decreases in the (relative) wages of low-skilled workers in industrialized economies and increases in those wages in developing countries. On average, though, individuals would be better off as a result of the overall economic efficiency gains triggered by trade liberalization.

Trade reform can, however, have employment effects if the economy was for some reason not characterized by full employment before the reform, or if some domestic policy or labour market characteristic hampers the adjustment process. For instance, in economies with a highly elastic labour supply, e.g. a large latent

\footnotetext{
14 See Mussa (1978) for a traditional (Heckscher-Ohlin) model with adjustment costs. The model shows how an economy moves from an autarky equilibrium to a trade equilibrium if adjustment takes time and is costly. One of the possible outcomes is that the economy never manages to reach the trade equilibrium that would be optimal in the absence of adjustment costs. It is worth noting that the "sticky" production factor in this model is capital and not labour.
} 
supply of labour in the rural areas before trade reform, exporters can expand production by attracting workers from those rural areas at existing wage rates. This situation is more likely to occur in developing countries and in such cases trade liberalization would lead to increases in formal employment levels rather than to changes in wages.

As for the interaction between labour market policies and trade policies, the theoretical literature has analysed a number of different setups that can explain a link between trade liberalization and unemployment levels. Minimum wages, for instance, keep wages above the equilibrium level for certain types of workers with the result that supply exceeds demand for those workers and there is unemployment. If those workers are mainly active in importcompeting sectors, then trade liberalization would further reduce demand for those workers and unemployment would increase. ${ }^{15}$ If, for instance, in industrialized countries minimum wages for lowskilled workers are higher than employers are willing to pay for their services, trade with developing countries could result in increased unemployment of low-skilled workers.

Other contributions to the theoretical literature have put more complex labour market models on top of a trade model. ${ }^{16}$ So-called efficiency wage models, for instance, assume that employers pay wages above the market clearing level in order to increase their productivity. Unemployment exists in the absence of trade, but trade reform may smooth or exacerbate the unemployment problem depending on its effect on the relative demand for different types of workers. Something similar happens in labour market models with search frictions, i.e. models in which laid-off workers and firms with

15 See Brecher (1974) for an early model on trade reform in the presence of minimum wages.

16 E.g. Matusz (1996) and Davidson, Martin and Matusz (1999). 
vacancies need time to find an appropriate match. If such models are combined with a trade model they give information on the net unemployment effects of trade and also provide insights into the effects on job destruction and job creation. ${ }^{17}$

The different models tend to have in common that changes in the relative demand for labour triggered by trade reform can result in increased unemployment of certain types of labour and decreased unemployment of other types of labour. In other words, labour market characteristics can explain why trade reform may result in unemployment effects rather than wage effects, but the underlying reason for these effects is the same in all cases: traditional trade models predict a change in the relative demand for workers. Some workers will be less in demand on the market than others, and the former will be affected negatively in terms of remuneration or in terms of their chances to find a job. It has, for instance, been argued that labour market characteristics explain differences in wage and employment trends in the United States and the European Union. While wage inequality between skilled and low-skilled labour has increased over time in the United States, unemployment rates of low-skilled workers have increased in the European Union.

The discussion so far would justify policy-makers' concern about worker transition between sectors and about the distributional effects of trade reform in the long run. More recent trade literature indicates that adjustment processes may not only be observed between sectors but that significant job reallocation may also take place within sectors. In particular, the traditional approach has been challenged by two types of new trade models: the sometimes called "new-new trade models" that introduce firm heterogeneity and fixed-market entry

17 See Jansen and Turrini (2004). 
costs into a trade framework, and a recent model of "task trade" used to evaluate the implications of offshoring. ${ }^{18}$

The new-new trade literature emerged in response to a number of empirical findings from the literature analysing plant level data that were at odds with the predictions of traditional trade models. Bernard and Jensen (1999) found that exporters in an industry tend to be more productive than other plants in the same industry. In a later paper they elaborate on this point and explain that the positive correlation between exporting and productivity levels appears to come from the fact that high productivity plants are more likely to enter foreign markets. ${ }^{19}$ The productivity path for a plant switching from being a non-exporter to an exporter shows a rise in productivity levels before and during entry, and a flat trajectory thereafter. Their results show that employment and output growth rates are much higher for exporters, and employment growth continues to increase after entry into foreign markets. From 1983 to 1992, more than 40 per cent of total factor productivity growth in the US manufacturing sector resulted from changing output shares across plants. Almost all of these re-allocative effects resulted from the fact that high-productivity exporters grew faster than lower-productivity non-exporters. Trade thus appears to promote welfare by facilitating the growth of high-productivity plants, not by increasing productivity growth at those plants.

The new theoretical trade literature reflecting these mechanisms has also implications for the employment effects of trade reform. In particular, it predicts that trade reform will trigger job creation and job destruction in all sectors, as both net-exporting and net-importing sectors will be characterized by expanding high-productivity firms

\footnotetext{
18 See Melitz (2003) and Helpman et al. (2003) for early papers of the "new-new trade theory" type and Grossman and Rossi-Hansberg (2006) on offshoring.

19 Bernard and Jensen (2004).
} 
and low-productivity firms that shrink or close down. ${ }^{20}$ The latter firms tend to be relatively small firms that do not manage to enter foreign markets and produce only for domestic consumers. For policymakers this implies that a lot of reshuffling of jobs takes place within sectors. ${ }^{21}$ This may be good news, as it is generally expected that it is more difficult for workers to move across sectors than to change firms within the same sector. A move across sectors may, for instance, imply higher retraining costs for workers and longer search periods. On the other hand the fact that adjustment occurs in all sectors implies that a wider range of jobs are at risk. While traditional trade models would suggest that policy-makers who wish to assist workers focus on so-called comparative disadvantages sectors, i.e. those that can be identified as import-competing sectors, more recent research suggests that such targeted intervention is not justified. Instead, this literature may explain why surveys in industrialized countries have revealed that workers in very different types of industries report greater perceived job insecurity as countries liberalize. ${ }^{22}$

Also the recent offshoring literature suggests that job destruction and creation will not take place according to a well established sectoral pattern. ${ }^{23}$ In addition this literature suggests that the cleavage of the labour market will not take place according to skill levels. Instead the key distinction lies in the tradability of services. Those tasks that can be provided at a distance are likely to be offshored. It has been argued that such jobs can be characterized by four features: IT

20 See in particular Bernard et al. (forthcoming).

21 Wacziarg and Wallack (2004) focus on the pattern of reallocation of labour following trade liberalization. They examine the impact of trade liberalization episodes on movements of labour across sectors for 25 countries, mainly developing and transition economies, and find weakly negative effects of liberalization on the extent of intersectoral labour shifts at the economy-wide 1-digit level of disaggregation. They find increased sectoral change after liberalization at the more disaggregated 3-digit level within manufacturing, although the estimated effects are statistically weak and small in magnitude. They also find that the effects of liberalization on labour shifts differ across individual countries, in a way related to the scope and depth of reforms.

22 See Scheve and Slaughter (2004).

23 Grossman and Rossi-Hansberg (2006). 
intensity, output that is IT transmittable, tasks that are codifiable, and that require little face-to-face interaction. ${ }^{24}$ Such tasks may include high-skilled jobs like security analysts or low-skilled jobs like switchboard operators and are not necessarily sector specific. All in all the impression that arises from the most recent trade and offshoring literature is that it will be increasingly difficult for policy-makers to predict the direction and nature of employment changes. ${ }^{25}$

\section{The evidence: trade and (un)employment}

The economic literature has produced a large number of empirical studies analysing the employment effects of trade. Different approaches have been taken to examine this question and so far no clear message emerges from the literature. The only general conclusion that may be justified is that employment effects depend on a large number of country-specific factors. A major shortcoming of the existing literature is that most studies of trade and employment refer to manufacturing employment, with little indication of whether their results can be generalized to agriculture or services, or indeed anywhere outside the formal sector. ${ }^{26}$

One major difficulty the relevant studies face consists in distinguishing the different possible causes of employment changes. Labour market policies, macroeconomic policies or movements along the business cycle are only a few examples of factors that may affect an economy's employment level. For instance, in their study on the impact of the Canada-US Free Trade Agreement, Gaston and Trefler (1997), made a distinction between the employment effects of the trade agreement and those of a general recession affecting both trading partners in the

\footnotetext{
24 Van Welsum and Reif (2005) and Van Welsum and Vickory (2006).

25 Baldwin (2006).

26 Hoekman and Winters (2005).
} 
same period. Similarly, other factors such as the job-search behaviour of workers also affect unemployment rates. Rama (2003), for instance, points out that temporary increases in unemployment following trade reform have been observed in many developing countries, even among successful developing country globalizers that could be considered as "models" in their own regions. However, he suggests that only a fraction of the unemployed concerned are out of a job due to globalization. Instead, unemployment is to a significant extent affected by so-called queuing for "privileged jobs", especially in the public sector, a common phenomenon among the educated urban youth. Notwithstanding those temporary surges in unemployment rates, Rama (2003) finds that unemployment rates do not appear to be systematically higher in more open economies.

The use of different methodologies and datasets can have a significant impact on the results economists obtain. For example, the studies by Gaston and Trefler (1997) and Trefler (2001) both analyse the employment effects in Canadian manufacturing following the free trade agreement between Canada and the United States. Gaston and Trefler (1997) find that tariff cuts contributed to reduced employment during the years following the agreement but that they also contributed to dramatic productivity increases leading to important long-run efficiency gains. In the first five years following the implementation of the FTA, Canada lost 390,600 jobs in the tradable sector. ${ }^{27}$ Gaston and Trefler (1997), however, show that those job losses were mainly due to economic recessions in both the Canada and the United States during the same period (recessions that were not caused by the FTA). In fact, as a result of the recession, exports and imports contracted over most of the five years following trade

27 As a consequence, calls for the re-negotiation and abandonment of the agreement enjoyed popular political support in Canada. 
liberalization. After controlling for the recession, it appears that FTAmandated tariff cuts accounted for only 9-14 per cent of the jobs lost over this period. In a more recent paper on the effects of the Canada-US Free Trade Agreement, Trefler (2001) finds instead a bigger role for the tariff cuts in the employment declines. According to his estimates, close to 30 per cent of the observed employment losses in manufacturing were a result of the FTA tariff cuts. In those industries that experienced the largest tariff cuts, as much as two-thirds of the 25 per cent reduction in employment is estimated to have been caused by the FTA. The fact that manufacturing employment has largely rebounded since 1996 suggests that the adjustment process lasted about seven years. During this adjustment process many workers moved to high-end manufacturing jobs, while at the same time there were dramatic productivity increases in low-end manufactures. Both aspects reflect important long-run efficiency gains from trade. ${ }^{28}$

Another difficulty that empirical studies on the employment effects of trade face is that it is not always straightforward to identify periods of trade reform. This is particularly true of industrialized countries that have tended to open up gradually over a relatively long time period. Much work on developed countries has therefore focused on the impact of exchange rate changes as opposed to trade reforms, the former representing a significant source of changes in terms of trade. ${ }^{29}$ One interesting finding of that literature is that changes in the trend of real exchange rates and cyclical changes have different effects on net employment. Using establishment panel data for the US, Klein, Schuh and Tries (2003) find that changes in the trend of the real exchange rate lead to a significant increase in job reallocation but do not affect net employment as both job destruction and job creation

\footnotetext{
28 Note also that Trefler (2001) finds increases in workers' annual earnings and that these increases are significantly higher in those industries that cut tariff rates most.

29 Hoekman and Winters (2005).
} 
increase. Instead, a cyclical variation affects job destruction and leaves job creation unaffected. As a result, a cyclical appreciation of the exchange rate reduces net employment. ${ }^{30}$

In industrialized countries there also appears to be concern about the stability of employment. It is, indeed, a popular idea that higher competition in goods markets, lower trade barriers and higher integration of goods markets across countries, higher globalization and outsourcing, are all leading to a more turbulent environment in terms of job destruction and job creation. When the environment becomes more turbulent, existing labour market institutions may become dysfunctional and lead to substantially higher unemployment. ${ }^{31}$ Blanchard (2005), however, points out that data do not support this idea. In the 1970s and 1980s the measures of reallocation - typically based on the standard deviation of rates of change of employment, either across sectors or across regions - showed no trend increase. The evidence as of the early 1980s is well summarized in Johnson and Layard (1986), who construct a table of standard deviations by industry or by region for a number of countries. Half of the standard deviations are higher in 1979 than in 1960, half are lower. In all cases, the changes are small. But perhaps, the increase in reallocation is taking place mostly within industries or regions, rather than across industries or across regions. In that respect, measures of job flows based on plant-level data are clearly preferable. ${ }^{32}$ The practical issue is that they typically do not go back far enough in time. But to the extent that they do, they also show little sign of increased turbulence.

30 Gourinchas (1999) finds that in France employment in traded-sector industries is very responsive to real exchange rate movements. The results in the paper indicate that a modest 1 per cent real appreciation leads to a decline in tradable employment of roughly 0.95 per cent, i.e. 35.000 jobs, over the course of the following two years.

31 Jansen and Turrini (2004) show in a model with frictional employment that increased volatility does not necessarily lead to higher unemployment.

32 For instance, along the lines of the work by Davis et al. (1996). 
Although the existing evidence appears to indicate that labour markets have not become more turbulent, Blanchard (2005) argues that the argument is not settled. He points to two reasons, one empirical, the other theoretical. The empirical reason is that other - admittedly conceptually less appropriate - measures of turbulence send a different message from job flows. For example, the measure of sales volatility constructed by Diego Comin and Thomas Philippon (2005), based on firm level data, shows a steady increase in volatility over time since the late 1960s. The evidence on flat job flows and increasing sales variability have yet to be reconciled. The theoretical reason is that one can construct models in which turbulence is not necessarily reflected in higher job flows, e.g. Ljunqvist and Sargent $(1998,2005)$. Increased turbulence is reflected in an increase in the specificity of skills associated with particular jobs. The implication is that an involuntary job change is associated with a larger drop in the wage distribution facing a laid-off worker than was the case in the past. In other words, turbulence does not lead to more volatile job markets but to stronger negative effects in the case of job loss. In such a scenario, if unemployment benefits are linked to past wages, the unemployed may have high reservation wages, and remain unemployed for a long time.

Studies on developing countries have tended to focus on the extent of (un)employment effects of trade liberalization rather than on changes in the volatility of labour markets. Many developing countries have reformed their trade regimes strongly in the recent past, which allows economists to analyse episodes of deep trade liberalization where the source of the shock can be clearly identified in time. ${ }^{33}$ This greatly facilitates the attribution of effects to trade, making the developing country-based literature more informative/robust in terms of its conclusions. 
A comprehensive, retrospective World Bank study of trade reforms conducted in developing countries found that in eight out of nine countries manufacturing employment was higher during, and one year after, the liberalization period than before (Papageorgiou et al. 1990). ${ }^{34}$ Only in Chile did manufacturing employment decrease significantly during and after trade liberalization. ${ }^{35}$ It has been argued, however, that institutional factors rather than trade liberalization explain this development. This view was confirmed by the analysis of Cox Edwards and Edwards (1996), who find that the effects of working experience and schooling outweigh the effects of trade liberalization on a Chilean worker's probability of becoming unemployed, as well as on the duration of unemployment.

The results of the Papageorgiou et al. (1990) study have, however, been challenged. ${ }^{36}$ Greenaway (1993) and Collier (1993) have questioned its findings primarily on methodological grounds. More recently, Agenor and Aizenman (1996) have pointed out that these studies provide only limited evidence on changes in employment in non-manufacturing production activities or changes in the aggregate unemployment rate. A more recent World Bank study on globalization (Dollar and Collier, 2001) takes a less sanguine view of the employment effects of trade liberalization than the earlier study. ${ }^{37}$ While reiterating the benefits of trade liberalization for both employment and wages over the long run, the study recognizes that there are significant transitional problems that need to be faced. It notes that "a series of case studies on the effects of trade liberalization

34 The study analyses thirteen liberalization periods in the following nine countries: Argentina (1967-70) and (1976-80), Brazil (1965-73), Chile (1974-81), the Republic of Korea (1978-79), Peru (1979-80), Philippines (196065) and (1970-74), Singapore (1968-73), Sri Lanka (1968-70) and (1977-79), Turkey (1970-73) and (1980-84).

35 Revenga (1995) also finds negative employment effects for the case of trade liberalization in Mexico during the period 1984-90. Yet, due to the study's focus on firm-level employment instead of total employment its results can only be taken as indirect evidence of the possible existence of adjustment costs in the case of Mexico.

36 See the discussion in Lee (2005).

37 Lee (2005). 
shows a considerable dispersion of the net impact on employment." More significantly, it highlights the problems that "small declines in employment hide substantial job churning" and that "some of the important losers from globalization will be formal sector workers in protected industries." Also the overview of a number of country case studies in Box 1 confirms that employment effects differ significantly across countries.

\section{Box 1: A selection of country case studies on the employment effects of trade reform}

Milner and Wright (1998) investigated labour market responses to trade liberalization in Mauritius. They show that manufacturing employment increased significantly in the period following the 1983 trade liberalization. Though employment increases in the long run exceeded those that occurred immediately after the trade liberalization, the short-run impacts on employment were significant and positive. Rama (1994), in contrast, finds a negative effect of trade liberalization on employment in his analysis of trade policy reform in Uruguay in the late 1970s and early 1980s. Further evidence on developing countries is given by Harrison and Revenga (1995) in a study cited by Matusz and Tarr (1999). They find evidence of increases in manufacturing employment following trade liberalization periods in Costa Rica, Peru and Uruguay. Instead, in a number of transitional economies (Czechoslovakia, Poland and Romania), employment fell during the transition period. As the authors note, however, those countries were also undergoing significant other reforms that went well beyond trade liberalization. 
Fu and Balasubramanyam (2005) use a panel data set for TVEs (Township and Village Enterprises) in 29 provinces in China over the time period 1987-1998, to analyse the effects of exports on labour demand. They find a positive and significant impact of exports on employment. A 1 per cent increase in export volume raises employment by 0.17 per cent. The labour demand elasticity of exports is similar to that of domestic production. This suggests that exports simply draw upon existing surplus productive capacity and labour and provide a vent for these surpluses. With a total number of employees of 125.4 million for the year 1998 in the township and village enterprises, a 1 per cent increase in total exports would have created about 213,000 job opportunities in the sector. During the 1998 to 2003 period, TVEs exports grew at a 15.5 per cent per year on average. For a country such as China with a large volume of underemployment, this means about 3 million job opportunities every year in the TVE sector fuelled by its fast export growth.

Bentivogli and Pagano (1999) analysed the effects of trade with the newly industrialized Asian economies on the labour markets of Germany, France, Italy and the United Kingdom. The analysis confirms that, despite the growing importance of this trade, problems in the European labour market cannot be explained by the increase in imports of manufactures from the Asian countries. In particular the authors find that workers' personal characteristics (gender and education) are significantly more important than exposure to import competition in explaining unemployment. 
The distributional effects of employment changes caused by trade have been analysed in a recent study of Madagascar, Nicita (2006). Madagascar's exports of textile and apparel products grew from about US\$45 million in 1990 to almost half a billion in 2001. Fueled by an increase in exports, employment in Madagascar's textile and apparel industry grew at a rate of more than 20 per cent per year in the late 1990s. The industry had an average earning premium of about 40 per cent over the average income of the workers in the informal economy. Yet Nicita's (2006) findings point to a strong variation in the distribution of the benefits from export growth with skilled workers and urban areas benefiting most. From a poverty perspective, exportled growth in the textile and apparel sector had only a small effect on overall poverty, according to the author. Nicita's (2006) study points to two reasons for this. First, a large majority of the poor are unable to enjoy the new employment opportunities, given their lack of the skills sought by the expanding textile and apparel export industry. Second, most of the poor reside in rural areas where the employment effect is small.

\section{TRADE AND INEQUALITY}

Economists have always been aware of the fact that the gains from trade are likely not to be distributed evenly within the population. Indeed, traditional trade models predict that there will be winners and losers from trade and that losers may even be worse off in absolute terms. This may not be a problem if the losers are individuals at the higher end of a country's income scale, but it may be if the opposite is the case. Inequality would then increase and depending on the extent of the change, governments may want to consider designing compensation mechanisms to redistribute some of the gains to those who lose. In fact, such mechanisms may be necessary in order to preempt resistance against trade reform. 
It is therefore important to have a good understanding of the link between trade and inequality and the trade literature has devoted a lot of attention to this question. First of all it is important to understand who are the losers: are they individuals at the high end or at the low end of the income scale, are they wage earners or capital owners, are they workers in the formal or in the informal economy? Observed increases in the wage premium, i.e. the difference between the wages of skilled workers and those of unskilled workers, appear to indicate that lowskilled wage earners have been losing out in recent years. Increased wage inequality and, more generally, income inequality appears to be a common phenomenon around the globe. ${ }^{38}$ But other factors than globalization may be driving such increases in skill premium, the first suspect being technological change. Economists have therefore tried to disentangle the two mechanisms, i.e. they have tried to distinguish changes caused by technological change from those caused by trade reform. The research discussed further on confirms that technological change is the main driver of inequality, which may also explain why increases in inequality have been observed in many developing countries, a phenomenon at odds with the predictions of traditional trade models.

Indeed, traditional trade models concentrate on explaining trade patterns and flows between significantly different countries. They have therefore been used to predict the outcomes of trade liberalization between industrialized countries on the one hand and developing countries on the other hand. But as a matter of fact industrialized countries trade far more with other industrialized countries than with poor countries. The question therefore arises, whether and how this phenomenon relates to the one of increased

38 This does not mean that all individual countries are affected by it. Ghose (2003), for instance, reports decreasing wage inequality in the Netherlands and in the United Kingdom for the period of 1980 to 1996. 
skill premiums. Is it only trade with countries like China and India which exercises downward pressure on low-skilled wages in Europe or does trade with the United States have similar effects? And what about the role of $\mathrm{FDI}$ and outsourcing in all this?

\section{Trade and inequality: what theory tells us}

(a) Trade and the relative demand for different types of labour

The classical link between trade and income inequality is based on the Stolper-Samuelson Theorem developed in a model that assumed full employment. According to this theorem inequality is most likely to increase in industrialized countries as a consequence of trade with developing countries, because the former are relatively well-endowed with skilled labour. ${ }^{39}$ Along the same lines, we would expect to see declining inequalities in developing countries. This would be the case because developing countries are typically well endowed with lowskilled labour relative to developed countries. When opening up to trade, developing countries will therefore be more competitive in lowskill-intensive-sectors and these sectors will expand. The increased demand for low-skilled workers, who typically belong to the poorer segments of the population, will lead to an increase of their wages relative to the wages of skilled workers. ${ }^{40}$

39 According to the Stolper-Samuelson theorem, some wages may even go down in absolute terms.

40 Increased openness may also lead to changes in asset distribution that can be to the advantage or to the detriment of the poor. Robinson (2000) illustrates this with the following example: "In the nineteenth century as transportation costs fell and the European economies developed and created a large market for tropical crops, Central American countries were ideally endowed to take advantage of the expanding world demand for coffee. In Costa Rica this led the government to pass laws in 1828, 1832 and 1840 allowing peasants to farm and gain title to frontier lands. This led to the creation of the famous class of Costa Rican yeoman farmers. In Guatemala the profitability of coffee instead induced a mass land grab by political elites in the 1870 s that led to the creation of large coffee estates and the re-introduction of colonial forced labour laws which lasted until the democratic interlude after 1945. As a result, land inequality is higher in Guatemala than in Costa Rica today, as is income inequality." 
The focus on the Stolper-Samuelson Theorem may be somewhat misplaced in the case of industrialized countries as the majority of their trade is with other industrialized countries rather than developing countries. Trade among industrialized countries often takes place within the same industries, i.e. Japan exports cars to the $\mathrm{EU}$ and vice versa. This so-called intra-industry trade therefore would not create the changes in relative demand for different production factors predicted by the Stolper-Samuelson Theorem. Recent contributions to the theoretical trade literature, like Manasse and Turrini (2001), have therefore looked at the question whether intra-industry trade may have an impact on the demand for high-skilled and low-skilled labour and come to the conclusion that intra-industry trade, i.e. trade among similar countries, can raise wage inequality within countries and also within sectors. Duranton (1999) comes to a similar conclusion in a model that combines intra-industry trade with technological change. In his model trade and technological progress will go hand in hand and together lead to increased wage inequality.

The role of technological change has also been examined in conjunction with trade of the "traditional" North-South type, i.e. trade between industrialized and developing countries by Zhu and Trefler (2005). In this model technological change takes the form of catch-up in the South. The model shows that technological catchup causes production of the least skill-intensive Northern goods to migrate South where they become the most skill-intensive Southern goods. Thus, the demand for skills and hence wage inequality rise in both regions. As a result inequality rises in both North and South according to a mechanism similar to the one described by Feenstra and Hanson (1997). ${ }^{41}$ Southern skill upgrading is also correlated with the

41 Feenstra and Hanson (1997) analysed FDI flows from the US to Mexico and found that it was related to activities that would be considered low-skill intensive in the US but relatively high-skill intensive in Mexico. As a result the relative demand for skills increased in both countries. 
trade-weighted average of Southern catch-up. The paper therefore provides some insight into the complex evolution of Southern inequality and its relationship to changing trade patterns.

(b) Trade, FDI and the possibility to substitute domestic workers by foreign workers

Recent literature has emphasized a second effect trade may have on labour demand. In addition to changing the level of demand for certain types of labour, trade may affect the sensitivity of labour demand to wage changes. It is argued that in an open economy employers would be more likely to threaten to lay off workers when they demand higher wages than in a closed economy. There are a number of reasons why this may be the case. Companies acting in an open economy face stiffer price competition than companies acting in a closed economy. More competitive product markets mean that a given increase in wages and thus costs translates into larger declines in output and thus demand for all factors. ${ }^{42}$ Economists refer to this increased sensitiveness as an increase in the price elasticity of labour demand. This increased elasticity reflects the fact that employers and the final consumers can substitute foreign workers for domestic workers more easily.

Labour demand elasticity may also increase as a consequence of increases in FDI. ${ }^{43}$ Suppose that a firm is vertically integrated with a number of production stages. Stages can move abroad either within firms as multinationals establish foreign affiliates or arm's length relationships by importing the output of those stages from other firms. Globalization of production thus gives firms access to foreign

42 Rodrik (1997), Scheve and Slaughter (2004).

43 Scheve and Slaughter (2004). 
factors of production as well as domestic ones, either directly through foreign affiliates or indirectly through intermediate inputs. This expands the set of factors firms can substitute towards, in response to higher domestic wages, beyond just domestic non-labour factors to include foreign factors as well. Thus, greater FDI raises labour demand elasticities. ${ }^{44}$

Ethier (2005) presents a model where globalization explains both the emergence of the skill premium and the presence of skillbiased technological change. His model assumes that outsourcing and unskilled labour are highly substitutable and that equipment and skilled labour are complementary, that production methods are flexible, and that the country undertaking outsourcing has a significantly different structure from that providing it. In this setup, a decrease in the cost of outsourcing will increase the skill premium in both countries. Increased globalization is also associated with increased fragmentation of production and more fragmentation is associated with a more elastic demand for unskilled labour. The model thus predicts a combination of outcomes that have been discussed in the literature and that have been prominent in the public debate.

There are two important differences between the mechanisms driving shifts in the demand for low-skilled labour discussed in the previous section and those driving the changes in the elasticity of demand discussed here. The first difference is that a shift in demand will mainly take place in the case of inter-industry trade, i.e. when countries with very different labour endowments trade. In contrast, price elasticity of demand can also change when similar countries trade, as a low-wage worker in one European country competes with a

\footnotetext{
44 This does not necessarily imply that workers abroad are "exploited." The authors point out that several studies have documented that establishments owned by MNEs pay higher wages than do domestically-owned establishments.
} 
low-wage worker in another European country. The second difference is that for the demand to shift, trade actually has to take place, whereas the price elasticity can be affected by the mere possibility of trade.

An increase in the price elasticity of the demand for labour could affect the position of (low-skilled) workers through a variety of channels. ${ }^{45}$ It may lead to lower labour standards or benefits, higher labour market volatility, a lower bargaining power of workers and/ or increased difficulties for governments to carry out redistribution policies.

With respect to the first effect, Rodrik (1997) elaborates that the costs for increased labour standards or benefits are usually shared by workers and employers. How these costs are shared depends on the price elasticity of the supply and demand curve for labour. An increase in the elasticity of labour demand will raise the share of the costs that will have to be borne by workers. In other words, it becomes more difficult for workers to make employers share in the cost of these benefits/standards and in order to maintain benefits/standards workers may have to accept lower wages.

Changes in the demand elasticity for labour can be linked to labour market volatility because an increase in the elasticity of labour demand results in larger shifts in labour demand in response to any type of economic shock. In other words, for the same level of economic volatility, wages and employment become more volatile. This makes workers feel more insecure and may also lead to increases in the skill premium if it is the case that low-skilled workers go through longer spells of unemployment and/or have to accept bigger wage losses after displacement. ${ }^{46}$

45 Rodrik (1997).

46 Scheve and Slaughter (2004), Rodrik (1997). 
The third argument relates to the bargaining power of workers. If domestic workers can be more easily replaced by foreign workers due to increased trade, the bargaining power of workers declines. ${ }^{47}$ This erosion of bargaining power may explain the loss of union membership in the United States and in many European countries in the recent past. ${ }^{48}$ The fourth impact, that of changes in the elasticity of labour demand on the governments' ability to redistribute, has been analysed in Spector (2001). The paper argues that trade liberalization reduces the ability of government to manipulate wages. In other words, trade liberalization eliminates one of the redistributive tools available in a closed economy and Spector (2001) shows that this can make it impossible to maintain everyone's welfare at the level reached before the opening of borders.

\section{The evidence: trade and wage inequality}

Much of the empirical work on trade and wage inequality for industrialized countries focuses on the relative importance of trade liberalization and technological change for changes in skill inequality in developed countries. The estimated impact of trade on the rise in skill differentials differs widely across the various studies. At the one extreme the studies of Berman, Bound and Griliches (1994) and Lawrence and Slaughter (1993) attribute a small or no role to trade, but an overwhelming role to technological change. ${ }^{49}$ On the other extreme

47 Robinson (2000) has argued that the military regimes in Chile and Argentina in the 1970s saw the power of their domestic opponents increase through trade liberalization, as the unions were strong in the import substitution sector.

48 See Jansen (2003).

49 Bhagwati (2000), instead, suggests that the effect of trade with poor countries on wage inequality in industrialized countries has been positive and has moderated the adverse impact on real wages in the North from other causes, like technical change. He argues that capital accumulation and technical change in the 1980s and early 1990s offset the effects of trade liberalization and resulted in a reduction of the relative supply of labour intensive goods. The net result of these forces would be an increase in Northern prices for labour-intensive manufactures, a phenomenon that has indeed been observed in the period mentioned. The changes exogenously emanating form the South thus push goods prices in the wrong direction and cannot be responsible for the decline of the real wages in the North. 
Wood (1994) attributes 70 per cent of the causation to trade. Cline (1997) provides a comprehensive overview of the existing literature and concludes: "A reasonable estimate based solely on the literature reviewed in this chapter would be that international influences contributed to about 20 per cent of the rising wage inequality in the 1980s." Cline's (1997) own empirical analysis generates different results: " ... about one-third of the net increase in the skilled/unskilled wage ratio from 1973-93 in the US was attributable to trade and an additional one-ninth was attributable to immigration."

More recent research into the causes of increasing wage inequality in industrialized countries attributes only a minor role to trade. To gauge the effect of international trade on the rising US skill premium, Haskel and Slaughter (2003) analyse the sector bias of price changes induced by changes in US tariffs and transportation costs. It is found that in both the 1970s and 1980s cuts in tariffs and transportation cost levels were concentrated in unskilled-intensive sectors. Despite this suggestive evidence, the authors estimate that price changes induced by tariffs or transportation costs produced a rise in inequality that was mostly statistically insignificant. Thus, they do not find strong evidence that falling tariffs and transport costs, working through price changes, produced rises in inequality.

It is notoriously difficult to identify trade effects on wages in transition economies, given that those economies have been subject to so many changes at the same time. One of the few studies analysing a transition economy is the paper by Goh and Javorcik (2004), that examines the impact of Poland's trade liberalization 1994-2001 on the industry wage structure. The liberalization was undertaken in preparation for Poland's accession to the European Union and was more pronounced in industries with larger shares of unskilled labour. The analysis indicates that a decrease in an industry 
tariff was associated with higher wages being earned by workers employed in the industry, when controlling for worker characteristics and geographic variables. The finding is consistent with liberalization increasing competitive pressures, forcing firms to restructure and to improve their productivity, which in turn translates into higher profits being shared with workers. It could also be potentially attributed to trade liberalization lowering the costs of imported inputs, which enhances firm profitability. The result holds when skilled workers are excluded from the sample, thus suggesting that reductions in trade barriers benefited the unskilled in terms of an increase in wages.

Empirical research into the link between trade and wage inequality in developing economies has produced mixed results. In particular there seems to be a difference between the effect trade has had on wage inequality in Asian countries as compared to Latin America. Most of the empirical evidence from East Asia confirms the predictions of traditional trade models, as the gap in wages between skilled and unskilled workers narrowed in the decade following trade liberalization (the 1960s in the Republic of Korea and Chinese Taipei, and the 1970s in Singapore). ${ }^{50}$ Wage differentials also decreased in Malaysia (between 1973 and 1989), but evidence on the Philippines is more ambiguous. ${ }^{51}$

In Latin America, evidence suggests that trade liberalization has coincided with an increase in both income and wage inequality. ${ }^{52}$ Argentina undertook trade liberalization between 1976 to 1982 and again from 1989 to 1993. The Gini coefficient rose from 36 in 1975 to 42 in 1981 and 47 in 1989 implying an increase in income inequality. ${ }^{53}$ The

50 Wood (1997).

51 ibid.

52 Data on income inequality are taken from Slaughter (2000). Information on skill differentials is taken from Wood (1997). The findings of Robbins (1996) go in the same direction.

53 The Gini coefficient is a measure of income inequality in an economy. The higher the value of the coefficient, the more unequal is the distribution of income. 
skill differentials in wages increased in the first period but narrowed in the second period. Chile liberalized between 1975 to 1979 and the Gini coefficient rose from 46 in 1971 to 53 in 1980. The wage gap between different skill levels also increased. Costa Rica liberalized from 1987 to 1993, the Gini coefficient increased from 42 in 1986 to 46 in 1989, and the wage gap also increased. Finally, during Mexico's liberalization episode from 1985 to 1988 the Gini coefficient rose - from 50 in 1984 to 54 in 1989. To the extent that poor workers in developing countries have a limited educational attainment, they would not be the main beneficiaries from globalization if openness goes hand in hand with an increase in the skill premium. ${ }^{54}$

Several explanations have been put forward for the differences in outcome between East Asia and Latin America. One line of argument focuses on the fact that Latin America opened its markets later than the East Asian economies (Wood, 1997). As a result, the entry of China and other large low-income Asian countries into the world market for labour-intensive manufactures in the 1980s shifted the comparative advantage of middle-income Latin American countries into goods of medium skill intensity. ${ }^{55}$ Increased openness in middle-income countries thus reduced the relative demand for unskilled workers by causing sectors of low-skill intensity to contract. This would explain why relative wages of unskilled workers decreased.

Another explanation for rising inequality in some developing countries is that liberalization introduces new skill-intensive activities into developing countries. For example, there is evidence that liberalization in Mexico induced larger FDI inflows from the United

\footnotetext{
54 Rama (2003).

55 It has also been argued that most Latin American economies are abundant in natural resources rather than low-skilled labour. This would also explain why wage inequality did not decrease in Latin America.
} 
States. ${ }^{56}$ These FDI flows reflected the shift of low-skill intensive activities from the United States to Mexico. ${ }^{57}$ Yet, Mexico's relative demand for skilled workers within industries in manufacturing rose along with FDI inflows into those industries, which led to increases in Mexican wage inequality. ${ }^{58}$ The explanation for this phenomenon is that jobs which were low-skill intensive in the United States were relatively skill-intensive in a country like Mexico.

The tariff schedule in place before trade liberalization will also affect the impact trade has on wage inequality. If protection was higher in the low-skill intensive sectors, then trade liberalization may actually lead to shrinkage of these sectors. As a consequence, wage inequality would increase. It has been suggested in the literature that this phenomenon has been observed in Mexico and Morocco. ${ }^{59}$

Attanasio et al. (2003) find evidence for a link between trade, skillbiased technological change and increases in wage inequality in line with the theoretical literature discussed before. They investigate the effects of the drastic tariff reductions of the 1980s and 1990s in Colombia on the wage distribution. They identify three main channels through which the wage distribution was affected: increasing returns to college education, changes in industry wages that hurt sectors with initially lower wages and a higher fraction of unskilled workers, and shifts of the labour force towards the informal economy that typically pays lower wages and offers no benefits. Their results suggest that trade policy affected each of the three channels. The

56 Feenstra and Hanson (1997).

57 See also the previous discussion of the paper by Zhu and Trefler (2005).

58 Currie and Harrison (1997) focus on another explanation for rising inequality in developing countries when liberalization occurs. They argue that the wage impact of liberalization depends crucially on the nature of product market competition. If increased product market competition reduces the relative price of low-skill intensive products, trade could have perverse wage-inequality effects. Currie and Harrison argue that this procompetitive effect of liberalization mattered in Morocco.

59 Hanson and Harrison (1999) and Currie and Harrison (1997) as quoted in Slaughter (2000). 
increase in the skill premium was primarily driven by skilled-biased technological change; however, the authors suggest that this change may have been in part motivated by the increased foreign competition to which the trade reform exposed domestic producers. With respect to industry wages, they find that wage premiums decreased by more in sectors that experienced larger tariff cuts. Finally, they find some evidence that the increased size of the informal economy was related to increased foreign competition as sectors with larger tariff cuts and more trade exposure experienced a greater increase in informality, though this effect was concentrated in the years prior to the labour market reform. However, the authors conclude that increasing returns to education, and changes in industry premiums and informality alone cannot fully explain the increase in wage inequality observed over this period, suggesting that overall the effect of the trade reforms on the wage distribution may have been small.

\section{The evidence: trade and income inequality}

Labour income represents only a fraction of total income and studies on wage inequality therefore only provide limited information on changes in income inequality. Developments in the agricultural sector, which still plays a predominant role in many developing countries, are not reflected in data on manufacturing wages. Also, wage data do not give any information on possible additional revenues of workers, for instance, through investments in shares. More importantly, changes in the returns to capital are not captured by the evolution of wage inequality. This is an important shortcoming in a time where concerns increase about the divergence between capital and wage income. ${ }^{60}$

60 On capital-wage inequality, see this quote by Rogoff (2005): "The simple truth is that corporations represent capital, and capital - in the form of factories, equipment, machines, money, and even houses - has been the single biggest winner in the modern era of globalization. Corporate profits are bursting at the seams of investors' expectations in virtually every corner of the world. Even in moribund economies like Germany and Italy, where employment security is vanishing, corporations are swimming in cash. This phenomenon comes as no surprise to economists. Add two billion Indian and Chinese workers to the global labor force, and the value of other means of production - particularly capital and commodities (for example, gold and oil) - is bound to go up. And so it has, with capitalists everywhere gaining an ever larger share of the economic pie." 
A number of empirical papers that have analysed the impact of trade reform on income inequality have yielded divergent results. Dollar and Kraay (2002) find that trade openness affects income distribution positively. A similar result is obtained by Behrman, Birdsall and Szekely (2001) for a set of Latin American countries. However, Sanchez-Paramo and Schady (2003) find the opposite result in six Latin American countries, where trade volumes would negatively affect inequality. Spilimbergo et al. (1999) and Barro (2000) also find that trade openness would be associated with higher inequality, whereas Edwards (1997) does not find any significant effect of trade on income distribution. This literature does not appear to allow for any general conclusions as to the link between trade liberalization and income distribution and the impression arises that this link is country and situation specific.

The recent market opening in China represents an interesting case study for economists and a number of studies have looked at the impact of trade on income inequality in this particular country. Together they provide interesting insights into what may be driving changes in income inequality related to market opening. Two different studies estimated that increased openness was accompanied by increases in the Gini coefficient in China from 38.2 in 1988 (28.8 in 1981) to 45.2 (38.8) in $1995 .{ }^{61}$ Yet another recent paper finds that across China, those cities that have had a greater increase in the trade-to-GDP ratio have also tended to witness a reduction, rather than an increase, in income inequality. ${ }^{62}$ Woo and Ren (2002) point out that trade has benefited the coastal provinces in China most, widening the income gap between the coastal and inland provinces. Yet, they argue, the gap was not the result of the rich getting richer and the poor getting poorer. Instead, all provinces appear to have gained from economic opening.

\footnotetext{
61 Cited in Wei and Wu (2001)

62 Wei and Wu (2001).
} 
Recent research has also examined the issue of whether trade and other variables have simultaneous effects on income inequality and growth. Lopez (2004) finds that improvements in education and infrastructure, and lower inflation, increase growth while reducing inequality i.e. these policies lead to both growth and progressive distributional change. Thus policies in these areas support both higher growth and lower inequality, and have a positive effect on poverty reduction. On the other hand, they find that financial development, trade openness, and decreases in the size of government are associated with increases in growth and in inequality. Such policies are therefore referred to by the author as win-lose policies, as they stimulate growth but increase inequality at the same time. In particular, the paper argues that in the short run, the positive impact of these policies on growth would not be enough to offset their negative impact on inequality. As a result, in the absence of pro-poor policies that accompany those reforms, or additional feedback effects from growth (such as improvements in education or infrastructure), poverty could actually increase in the short run. Lundberg and Squire (2003) come to similar conclusions with respect to the positive impact of open trade regimes on both growth and inequality.

\section{The evidence: trade, FDI and the possibility to substitute domestic workers by foreign workers}

(a) Does globalization affect labour demand elasticities?

Various contributions to the empirical literature have examined whether the demand for labour has become more sensitive to wage changes as a result of trade. So far, direct evidence on the effect of trade liberalization on labour demand elasticity is mixed. Slaughter (2001) tries to determine whether international trade has been increasing the own-price elasticity of demand for US labour in recent decades. 
He finds that over time demand for production labour has become more elastic in manufacturing, and in five of eight industries within manufacturing. The elasticity fluctuated around -0.5 until the mid1970 s, but then moved steadily to around -1.0 by 1991 . Non-production labour demand has not become more elastic in manufacturing overall or in any of the industries within manufacturing. Almost all estimates range somewhere between -0.5 and -0.8 , and if anything, demand seems to have become less elastic over time. Slaughter (2001) also tries to identify determinants of changes in the price elasticity of labour demand and his findings provide only mixed support for the hypothesis that trade contributed to increases in these elasticities. ${ }^{63}$

Hasan, Mitra and Ramaswamy (2003) looked at how major trade reforms initiated in India in 1991 affected labour-demand elasticities in the manufacturing sector. ${ }^{64}$ Their findings suggest that labourdemand elasticities increase with reductions in protection. ${ }^{65}$ The paper also finds that after reforms, productivity and output volatility resulted in larger wage and employment volatility. Fajnzylber and Maloney (2005) question the theoretical link between liberalization and labour-demand elasticities and find confirmation in their empirical results. Using dynamic panel techniques to estimate labour-demand relations for manufacturing establishments in Chile, Colombia and Mexico across periods of trade

63 For production labour, many trade variables have the predicted effect for specifications containing as regressors only these variables, or them plus industry-fixed effects. However, these predicted effects generally disappear when time controls are included. For non-production labour, things are somewhat better. Four possible trade variables - narrow and broad outsourcing, the foreign-affiliate share of US multinational corporations' assets, and net exports as a share of shipments - have the predicted sign at least to the 90 per cent level of significance even when both industry and time controls are included. For both labour types, time itself is a very strong predictor of elasticity patterns.

64 Their data are disaggregated by state and industry and are for the period 1980-97. Given the variation across industries and over time in protection levels, and the variation across states in labour market institutions, the authors are able to decompose the effect of protection and labour regulations on labour demand elasticities and at the same time look at the interactions between the two. See the discussion in Section E.1 of this study.

65 Unlike Slaughter (2001), the authors do not find time, independent of protection, to dominate their results. 
policy reform their findings do not strongly support the hypothesis that trade liberalization has a direct impact on own-wage elasticities.

(b) Globalization, insecurity and the bargaining power of workers

Increases in the price elasticity of labour demand can lead to a number of changes in the working environment. They may, for instance, lead to a reduction in the bargaining power of workers and to increases in the volatility of labour market outcomes. A number of recent empirical studies have focused on this indirect evidence of changes in the elasticity of labour demand. Slaughter (forthcoming) finds a statistically and economically significant correlation between falling union coverage in the US and increases in inward FDI transactions. Since the affiliates of foreign multinationals investing in the US actually have higher unionization rates than US-based firms, this correlation cannot reflect a compositional shift towards these affiliates. Rather, it is more likely to reflect changes in the bargaining power of workers in US companies consistent with the theoretical relationship between $\mathrm{FDI}$ and labour demand elasticity.

An increase in the elasticities of labour demand can also affect perceptions of economic insecurity. Scheve and Slaughter (2004) analyse panel data from the United Kingdom over the 1990s and find that industries' level of FDI activity is positively correlated with individual perceptions of economic insecurity of workers employed in these industries. To be more precise, they find that individuals more exposed to FDI activity are more likely to report greater insecurity and also that changes in exposure for a single individual, controlling for previous levels of insecurity, are correlated with changes in worker 
insecurity. ${ }^{66}$ The authors regard the individual-level panel results as the first valid evidence consistent with a causal relationship between globalization and worker insecurity.

A number of scholars have argued that increases in economic insecurity from globalization may generate demands for more generous social insurance that compensates workers for a riskier environment (e.g. Rodrik, 1997; Burgoon, 2001; Hayes, Ehrlich and Peinhardt, 2002; Boix, 2002). At the same time many scholars have also suggested that globalization limits the capacities of governments to provide such compensation (e.g. Rodrik, 1997; Desai, 1999; Besley, Griffith and Klemm, 2001). Thus, individuals may be concerned about globalization because they believe it reduces the insurance provided by the state for all labour market risks, including those heightened by global integration.

\section{E. THE ROLE OF POLICY-MAKERS}

The discussion so far has shown that the employment and income effects of trade liberalization, and of globalization more generally, have differed significantly across countries. This is not entirely surprising as countries differ immensely, for instance, in their climatic conditions, their cultural heritage, political structure and domestic institutions like the legal system and labour market institutions. This section attempts to shed some light on how domestic institutions can affect the relationship between trade and employment. In particular, it tries to provide some insights into possible trade-offs between the intended effects of policies or institutions and their unintended side effects. The domestic institutions and policies discussed in this

66 I.e. the positive relationship holds in yearly cross-sections, in a panel accounting for individual-specific effects, and in a dynamic panel model also accounting for individual-specific effects. 
section tend to pursue one or a combination of three policy goals: they aim at reducing inequality, at providing insurance against adverse professional events and/or at enhancing the functioning of markets. The negative side effects typically take the form of efficiency losses as policy interventions may change incentives in one way or another and therefore introduce distortions into the economy.

\section{Labour market institutions}

Labour market institutions are part of the governance structure of both industrialized and developing countries. They typically consist of:

i) labour legislation (and a corollary administrative structure) to ensure basic rights at work; to regulate the terms of employment contracts covering aspects such as minimum wages, employment security, working time and conditions of work; and to provide social benefits such as health care and pensions,

ii) institutions for collective bargaining and for social dialogue: that is, consultations between government, trade unions and employer organizations on labour market issues,

iii) government agencies responsible for the formulation and implementation of policies relating to the functioning of labour markets and to skill development, and active measures to promote a higher level of employment.

There are significant differences among countries in the extent of coverage and in the specific form these institutions take. Nevertheless, there is an international consensus on the basic principles and rights (spelled out in the ILO's Declaration on Fundamental Principles and 
Rights at Work of 1998). These principles and rights include freedom of association, the right to collective bargaining, and non-discrimination. In addition, there is also a broad international recognition of the value of social dialogue.

The coverage and nature of labour market institutions and policies have an influence on the economic and employment outcomes associated with trade and related economic liberalization programmes. For example, they affect the social impact of adjustment; the incentive for workers to seek, and for employers to create, new jobs; and the extent of wage inequality. It is thus important to review the literature on how various aspects of labour market institutions affect the outcomes from trade liberalization.

\section{(a) Insuring workers against adverse professional events}

Modern economies need to constantly reallocate resources, including labour, from old to new products, from bad to good firms. ${ }^{67}$ At the same time, workers value security and insurance against major adverse professional events, job loss in particular. In response to this, economies have used different tools to provide a buffer against the most negative consequences of job loss. These tools include: job-security regulation that makes it harder for employers to lay off workers and unemployment benefits that provide workers with a certain level of income during periods of unemployment. However, both types of policies, may negatively affect the reallocation process, i.e. the process of creative destruction inherent to the growth process and also to the adjustment process following trade liberalization. The question therefore arises, whether and to what extent a trade-off between efficiency and insurance exists. 
Concerns have been expressed as to the potential impact of jobsecurity regulation on the speed of adjustment to trade and related economic reforms. ${ }^{68}$ The literature on the impact of labour market regulation on the many different economic, political and sociological variables associated to labour markets and their participants is extensive and contentious. However, the proposition that job security provisions may reduce restructuring is a point of agreement. Job security provisions increase the cost of reducing employment and therefore lead to fewer dismissals when firms are faced with negative shocks. Conversely, when faced with a positive shock, the optimal employment response takes into account the fact that workers may have to be fired in the future, and the employment response is smaller. The overall effect is a reduction in the speed of adjustment to shocks.

The paper by Caballero et al. (2004) analyses this relationship empirically and analyses how cross-country differences in job security regulation affect the speed of adjustment. Its methodology builds on the simple partial-adjustment idea that larger adjustment costs are reflected in slower employment adjustments to shocks. ${ }^{69}$ The authors find that job-security regulation clearly hampers the creativedestruction process, especially in countries where regulations are likely to be enforced. Moving from the 20th to the 80th percentile in job security, in countries with strong rule of law, cuts the annual speed of adjustment to shocks by a third while shaving off about 1 per cent from annual productivity growth. The same movement has negligible effects in countries with weak rule of law.

Bolaky and Freund (2004) go a step further and argue that slow adjustment caused by rigid regulation can reduce the growth effects

68 These concerns are not limited to developing countries.

69 Note that this paper is not specific to trade shocks. 
of trade liberalization. They examine the effect of openness on growth using cross-country regressions with data from more than 100 countries. Results from level regressions imply that increased openness is, if anything, associated with a lower standard of living in heavily-regulated economies. ${ }^{70}$ The logic is simple: if the structure of economic activity is rigid, then trade only has a modest impact on the allocation of resources across and within industries. Moreover, to the extent that the production structure does not change, excessive regulation may encourage increased production of the wrong goods - those the country is not relatively efficient to produce.

However, other contributions to the literature have cast doubt on the linkage between job security policy and adjustment to shocks. Wacziarg and Wallack (2004) try to account for the impact of job security policy on structural change following trade liberalization and find contradictory evidence when using different samples. Their results therefore do not allow for any general conclusions. It is also important to remember the initial aim of job security policy, i.e. that of reducing insecurity for workers. Hasan, Mitra and Ramaswamy (2003) find that the response of labour-demand elasticities to protection is conditioned by the nature of labour institutions: Indian states with more flexible labour markets see larger increases in labour-demand elasticities in response to reductions in protection. This finding indicates that there may indeed be a trade-off between efficiency and insurance.

70 The authors' index of regulation is composed of data on labour regulations and business entry regulations drawn from the "Doing Business" dataset of the World Bank. Their labour regulation index consists of the logarithm of an employment laws index, where the latter reflects how regulated the labour market is and is constructed through an examination of detailed provisions in the labour laws of each country. The employment laws index is an average of three indices covering flexibility of hiring, conditions of employment and flexibility of firing. The authors also use an index of entry regulations, using data on the number of procedures and time it takes to start a business in each country. 
Blanchard (2005) asserts that a trade-off between efficiency and insurance exists, but emphasizes that the experience of some successful European countries suggests it need not be very steep. Sapir (2006) comes to a similar conclusion when comparing four different European social models in their potential to generate high employment rates - efficiency according to his definition - and to keep the risk of poverty low - equity in his terminology. He concludes that the Nordic model manages to be both efficient and equitable. ${ }^{11}$

Much of the impact of job-security legislation appears to depend on the way it is designed. Blanchard (2005) argues that it is important to protect workers, not jobs. This means employment protection, but in the form of financial costs to firms to make them internalize the social costs of unemployment, including unemployment insurance, rather than through a complex administrative and judicial process. This means dealing with the need to decrease the cost of low-skilled labour through lower social contributions paid by firms at the low wage end, and the need to make work attractive to low-skilled workers through a negative income tax rather than a minimum wage. The idea of a negative income tax, i.e. an income subsidy, has also been discussed in the context of redistribution policies and will be raised again later on in this study.

(b) Facilitating transition following trade reform

Trade liberalization leads to a reshuffling of economic activities as the result of which economies are expected to be better off. But the transition period may involve some hardship, in particular for workers whose jobs are threatened by trade liberalization. Those workers may have to look for a new job and potentially have to go through a

71 In this paper the group of Nordic countries includes Denmark, Finland, Sweden and the Netherlands. 
period of unemployment. They may be expected to relocate or to reeducate. Two types of labour market policies targeting this transition process can be distinguished: (passive) income support during periods of unemployment and so-called active labour market policies that attempt to facilitate re-employment.

(i) Social protection and the potential role of the international community

Financial markets typically fail to help the jobless both in industrialized and developing countries. But while many industrialized countries have developed social protection systems to assist individuals concerned, developing countries are typically unable to afford adequate protection. For the poor in such countries, "even switching from one unskilled informal sector job to another could cause severe hardship." ${ }^{\prime 72}$

Numerous industrialized countries, in particular in the European Union, are characterized by rather generous social protection systems. But these systems differ significantly when it comes to the detail. Often, income support during unemployment is calculated as a percentage of the most recent salary while employed. These percentages differ significantly across countries, but in general this approach implies that high-skilled workers are also better off during unemployment than low-skilled workers. Different rules also exist as to the length of unemployment benefits and as to the level of income support to workers that remain unemployed for many years. The economic literature has pointed at the need to design systems such that the unemployed continue to have incentives to look for new jobs. In this context, Blanchard (2005)

72 Winters (2000). 
argues that it is important to provide generous unemployment insurance, but that it ought to be conditional on the willingness of the unemployed to train for and accept jobs if available. In industrialized countries numerous examples exist of adjustment programmes directed at specific regions or sectors. The US Trade Adjustment Assistance programme specifically targets workers who have lost their jobs as a result of changes in trade flows and the European Union recently decided to introduce a similar programmes. $^{73}$

Social protection in low-income countries is typically confined to the minority of workers who are in the formal sector. This is because it is difficult to introduce systems of social insurance for workers in the informal and agricultural sectors who are outside the fiscal system; levels of poverty are also high in these sectors. The major challenge faced by low-income countries is thus that of devising and extending alternative means of providing social protection to the informal economy. Such alternative measures, which have been experimented with in some countries, have included local self-help initiatives to provide insurance against illness and loss of income; active labour market policies such as employment guarantee schemes based on labour-intensive rural and urban public works programmes; and various forms of micro-credit programmes to promote productive selfemployment. While such measures have played a useful role in specific local contexts they all face the problem of "scaling up" - increasing their coverage to all those who are in need.

73 There is no agreement in the literature as to the success of specific trade adjustment programmes in facilitating adjustment. In the United States it has been suggested that the Trade Adjustment Assistance programme should enlarge its scope and provide compensation to displaced workers for permanent income losses. In other words, it has been suggested to use the programme also as a redistributive tool. See also the discussion on redistribution in this study. 
In middle-income countries where formal employment is more significant there is often more scope for providing social protection to workers who are adversely affected by trade and related economic reforms. However, very few of these countries have systems of unemployment insurance even though such schemes are financially and organizationally feasible. Progress in these areas would clearly strengthen the capacity of these countries to cope with the economic and social impact of trade liberalization and other economic reforms.

To the extent that the introduction of wide-ranging social protection systems in low and middle income countries takes time, the literature has discussed the possibility of introducing programmes of limited duration, targeting those negatively affected by trade reform. Although there does not seem to be a clear understanding of how precisely such programmes should be designed, one can envisage that they could constitute an element of so-called "aid for trade" packages financed by the international community.

\section{(ii) Active labour market policies}

Active labour market policies are intended to facilitate the reintegration of the unemployed into the labour market as well as the reallocation of labour necessitated by structural change or geographical, occupational, and skill mismatches. They include measures such as retraining schemes for displaced workers, job-search assistance, direct employment creation programmes such as public works schemes, credit and training programmes to promote selfemployment ${ }^{74}$; and employment subsidies to promote the hiring of

\footnotetext{
74 The German "Überbrückungsgeld", for instance, refers to a state-supported credit programme for unemployed who wish to start their own company.
} 
vulnerable groups such as low-skilled workers and new entrants to the labour force.

Active labour market policies may also be a useful tool to facilitate adjustment to changes in the structure of production brought about by trade liberalization. Measures to provide retraining for displaced workers and job search assistance to facilitate labour mobility will be important in this connection. ${ }^{75}$ Evidence on the effect of retraining programmes on unemployment duration and wage levels in the context of trade liberalization is scarce and comes to mixed results. ${ }^{76}$ Rama (1999) indicates that it may be important for retraining to focus on the acquirement of new skills rather than on the updating of previous skills. The work by Falvey et al. (2006) highlights that the appropriate policy may differ across countries, depending on their level of income and on the skill and age composition of the working population. Their results suggest that trade-adjustment-assistance should focus on older-unskilled workers in skilled-abundant countries and younger-skilled workers in unskilled-labour-abundant countries.

Active labour market policies are widely used in industrialized countries where they are increasingly being seen as a preferable alternative to passive income support to the unemployed. Coupled with measures to increase the incentive (and obligation) to seek work, such measures can help to raise the employment rate, especially in a context of positive overall employment growth. Hybrid systems of income support and active labour policies have also been suggested. Heitger and Stehn (2003), for instance, propose the reinterpretation of the unemployment insurance system as an employability insurance system. Under such a system, individuals who are laid off could take

75 See Lee (2005).

76 Bacchetta and Jansen (2003). 
their insurance entitlement and use it to finance the investment in human capital necessary to regain employability. In some countries, such as the United States, active labour market policies have also been specially targeted at workers who have been adversely affected by trade liberalization.

While many developing countries do implement elements of active labour market policies such as public employment services, skill development programmes, and various direct employment creation schemes, the scale of such interventions and the resources devoted to them is typically limited. The programmes are also often poorly designed and managed. Strengthening the capacity of these countries to design and implement such programmes, especially ones that are targeted at workers adversely affected by trade and related liberalization, will clearly enable them to cope better with the social impact of economic reforms as well as help to increase popular support for the reforms themselves.

\section{(c) Freedom of association and collective bargaining}

Freedom of association and the right to bargain collectively are the foundational elements of rights at work. Although, as mentioned earlier, there is an international consensus on the importance of respecting these rights there has nevertheless been a debate on their economic effects in developing countries. Some developing countries have expressed concerns that the full exercise of these rights could have a negative impact on their economic competitiveness. This concern derives from the view that a high level of unionization and collective bargaining could lead to an excessive rise in labour costs that erodes their comparative advantage, based on low wages, as well as lead to labour market rigidities that retard required adjustments in the structure of employment. 
However, as will be seen below, there has been little empirical support for this view in the economic literature. It is also important to point out that the focus on the economic effects of fundamental worker rights in the context of trade competitiveness overlooks other important dimensions of these rights. Apart from being a part of universally recognized Human Rights, they have clearly positive effects through enabling social dialogue between workers, employers and governments; this is invaluable for promoting broad social support for economic reforms as well as a more equitable distribution of the burdens and benefits from trade liberalization.

A number of recent studies have analysed whether labour market characteristics affect economies' responses to trade liberalization. Kucera and Sarna (2006) use a bilateral trade gravity model to evaluate the effects of freedom of association and collective bargaining (FACB) rights and democracy on exports, evaluating exports by labour intensity for the 1993 to 1999 period. The model includes data for up to 162 countries and employs a number of indicators of FACB rights and democracy, including those constructed by the authors based on the coding of textual sources, the OECD FACB indices, the Freedom House civil liberties and political rights (democracy) indices. The paper finds robust relationships between stronger FACB rights and higher total manufacturing exports as well as between stronger democracy and higher total exports, total manufacturing exports and labour-intensive manufacturing exports. The paper finds no robust relationship between $F A C B$ rights and labour-intensive manufacturing exports. These results suggest that FACB rights do not harm the export potential of developing countries and may even stimulate it.

This may explain why Neumayer and de Soysa (2006) do not find evidence of a race to the bottom in FACB rights. Using the measure for FACB rights constructed by Kucera and Sarna, the authors find that 
countries that are more open to trade have fewer rights violations than more closed ones. This effect holds in a global sample as well as in a developing country sub-sample and holds also when potential feedback effects are controlled for via instrumental variable regressions. The extent of an economy's "penetration" by FDI has no statistically significant impact on the violation of rights. The authors conclude that while globalization might not be beneficial for outcomerelated labour standards, it is likely to promote the process-related standard of a right to free association and collective bargaining.

Other empirical papers analyse how union activity affects the employment and wage response to trade reform and the overall adjustment path following reform. Griffith et al. (2006) use timevarying information on product market reforms to test theoretical predictions that higher levels of competition increase employment and real wages. They also examine whether the increase is larger for employment and smaller for real wages when workers' bargaining power is higher. Empirically, the paper shows that the significant product market deregulation experienced in the 1990s by some OECD countries was associated with an increase in competition as measured by average firm profitability. Such exogenous increases in competition were further associated with increases in aggregate employment and the real wage. They estimate that in countries with higher levels of collective bargaining coverage and/or union density the increase in employment is more pronounced, and the increase in real wages less so.

Forteza and Rama (2001) compare the impact of different labour market characteristics on an economy's propensity to adjust. ${ }^{77}$ In

77 The study looks at adjustment to "economic reform programmes" financed by World Bank adjustment credits and loans. 
addition to minimum wages and non-wage costs, the authors include the level of unionization and the size of government employment in their measures for labour market rigidity. The results of their empirical analysis show that countries where organized labour is potentially influential are more likely to experience recessions immediately before adjustment and slower recovery afterwards, whereas growth performance is not affected by the level of minimum wages and non-wage costs. They argue that the resistance of organized labour to reform may have induced policy-makers to redesign original reform packages and introduce conflicting elements, with the result that reforms become less effective. Spector's paper (2004) can help to understand the reasons for resistance to reforms. The paper focuses on product market deregulation and shows that widespread opposition to product market deregulation does not necessarily reflect workers' myopia. It may instead constitute a rational attempt to protect the rents that workers as a whole extract at the expense of firms' shareholders. Indeed, more intense competition may cause wages to fall in the long run, even when general equilibrium effects and the long-run adjustment of the capital stock are taken into account. ${ }^{78}$ If both labour and product markets are very regulated, the beginning of the deregulation process is therefore a very difficult political step. Since the distributional effect of product market deregulation may prevent the building up of sufficient political support, Spector (2004) argues that it may be necessary to complement deregulation with fiscal redistribution.

78 Note that Spector's model does not fit the evidence by Griffith et al. (2006) discussed above. 
(d) Trade reform and the informal economy in developing countries

A key differentiating feature of the structure of employment in developing countries is the fact that a high proportion of total employment is in the informal economy. This has important implications for the impact of trade liberalization on employment, inequality, and poverty in these countries. A fundamental issue is how trade liberalization affects output, employment, and incomes in the informal economy. A priori reasoning suggests that this effect can be both positive and negative.

The informal sector takes on a substantial proportion of the economies of many developing countries, some as high as 70-80 per cent and reaching 90 per cent in India when the agricultural economy is considered as a major section of the informal sector (Marjit and Maiti, 2005). The informal economy is estimated at 50-60 per cent in Colombia (Goldberg and Pavcnik, 2003) while non-registered workers accounted for 40 per cent of the Brazilian workforce in 1999 (Soares, 2005). On a broader scale, Charmes (1998) notes that the share of the non-agricultural workforce ranged from over 55 per cent in Latin America to 45-85 per cent in different parts of Asia and to nearly 80 per cent in Africa. ${ }^{79}$

Dual labour markets are an important feature of developing countries and if trade is to be considered as an important development tool in these economies, it must in the very least have a positive impact on the informal sector. Pertinent issues of concern to policy-makers and activists alike usually border on the transforming relationship between the formal and informal economy as a country goes through

79 See also Carr and Chen (2002). This paper also looks at gender impacts of globalization. 
phases of trade liberalization. Does the increased competition that comes with trade liberalization reduce formal sector employment and wages in developing countries while expanding the informal economy and reducing wage levels there simultaneously? Or does trade liberalization bridge the gap between formal and informal economy wages, thereby reducing inequality? If the answer to the latter question is in the affirmative, the direction of this bridge should be of concern: whether previously high wage earners are worse off or low wage earners are better off with the introduction of trade liberalization.

Arguments in support of both directions of change can be found in the literature. It has often been argued that globalization has led to a rise in informality. This statement is based on the following rationale. Trade reforms expose establishments in the formal sector to increased foreign competition. In response, such establishments try to reduce labour costs by cutting worker benefits, replacing permanent workers with part-time labour, or subcontracting with establishments in the informal economy, including home-based and self-employed micro-entrepreneurs. Firms in the formal economy may also lay off workers who subsequently seek employment in the informal economy. On the other hand it has been argued that globalization creates new opportunities in the form of new jobs for wage-workers and new markets for the self-employed in particular in export oriented activities. According to this argument globalization has a strong potential to reduce the role of the informal economy. ${ }^{80}$

The nature of labour market institutions and policies in developing countries is also often believed to have an influence on how trade liberalization impacts on the informal economy as well as on the level and structure of employment. In particular, it has been argued that the

80 Kapoor (2005). 
extent of labour market regulation, especially employment protection, will influence the distribution of employment between the formal and informal economies in the aftermath of trade liberalization.

The existing empirical evidence on the relationship between trade and the informal economy is still limited and inconclusive. This is not surprising as the informal economy is largely undocumented, which makes data collection very difficult. Some work in this area has, however, been done on Brazil (Soares, 2005), Brazil and Colombia (Goldberg and Pavcnik, 2003) and India (Marjit and Maiti, 2005).

Goldberg and Pavcnik (2003) examine the link between trade liberalization and the incidence of informality in Brazil and Colombia. Their results for Brazil show no relationship between trade policy (tariffs in particular) and informality and this remains unchanged with the inclusion of different control variables and using different estimation methods. In contrast, trade variables are on average significant for Colombia. Decreases in tariffs are associated with a higher probability of informality. The authors attribute the different impacts of trade reform on the informal economy between Brazil and Colombia mainly to differences in labour market policies. In one exercise they control for Colombia's labour market reforms in 1990, that significantly reduced the cost of firing a worker and increased labour market turnover. Their results suggest that tariff declines are associated with increases in the probability of informal employment prior to labour reforms when the costs of firing formal workers were high. In contrast, a tariff decline in an industry is associated with a smaller increase and a potential overall decrease in the probability of informal employment after the reform.

Soares (2005) seeks to identify links between trade liberalization and the fall in the Brazilian wage differential and also examines 
possible links between trade liberalization and the proportion of non-registered workers. The author finds that import penetration impacted negatively on wage differentials but had no effect on the proportion of registered workers. Tariffs negatively affected the proportion of registered workers without having any effect on wage differences. In other words, industries most affected by a reduction in effective tariffs also experienced increases in the proportion of registered workers. Even if trade liberalization cut wage premia of registered workers, it increased the proportion of registered workers in some sectors.

Marjit and Maiti's (2005) survey for India reports significant organizational change regarding the linkages between formal and informal production units in a period of increased openness to trade. They document a decline in independent and cooperative units from 44.38 per cent to 41.85 per cent and 34.56 per cent to 12.64 per cent in 2001 respectively. Tied units proved to be a dominant tendency. These are units that have strong links with a "merchant capitalist" or middleman mostly located in towns. Crafts persons in tied units make products according to the design and on order from the merchant capitalist. The artisans may possess the tools and the workshops, but they are under tight control from the traders. Trade liberalization brought with it expanding national and export markets for rural artisans who hitherto depended mainly on small rural markets. With the help of export merchants and marketing agencies, hornware products are exported to Germany and Japan, hand loomed products to Japan and brassware for regional markets. As export markets expand, the informal rural industries exhibit increasing dynamics of tying, technology adoption and growth.

From a policy perspective it appears important to undertake more empirical studies to improve our understanding of how trade 
liberalization affects the informal economy. This will enable policymakers to frame trade policies that aim at minimizing any possible negative impacts of trade liberalization on the informal economy and/ or at strengthening its positive impacts. It may also help to design accompanying policy interventions if these are useful to ensure that the informal economy benefits more from trade liberalization.

\section{Redistribution policies}

It has been discussed before that traditional trade models predicted that trade would lead to a rise of the wage premium in countries relatively well endowed with skilled labour and a rise of the capital-wage-ratio in countries relatively well endowed with capital. It comes therefore as no surprise that economists have attempted to analyse the effect of redistribution policies within these models. Using a traditional, full employment model of trade Dixit and Norman $(1980,1986)$ have argued that it is possible to use commodity taxes to compensate the losers without exhausting the benefits from freer trade. Brecher and Choudhri (1994) have raised concerns about this result by showing that in the presence of unemployment this scheme may not work. Instead, they show that in such a setting and under reasonable conditions, fully compensating the losers may eat away all of the gains from trade. Feenstra and Lewis (1994) have shown that similar problems arise when factors of production are imperfectly mobile.

In the past two decades many public finance economists have focused their attention on the incidence and optimality of taxes when factor markets become more integrated. One standard model is built on the assumption that capital becomes more and more mobile across countries or regions, while labour is rather less mobile 
or even assumed to be immobile. ${ }^{81}$ Increasing mobility of capital has important consequences for tax policy because a higher elasticity of capital relative to labour would call for lower tax rates on capital on efficiency grounds. This has at least partly undesirable distributional consequences. In particular, it significantly restricts the possibilities for governments to redistribute from capital to labour. Several contributions to the literature have recommended international tax coordination or even tax harmonization in order to reduce the strong downward pressures on the taxation of capital income. ${ }^{82}$ International tax coordination would allow countries to reap the benefits of capital mobility, while compensating the losers of increased openness.

Other contributions to the literature have focused on the trade-off between the aim to redistribute and the efficiency losses introduced by redistribution policies. Davidson and Matusz (forthcoming) develop a model that allows them to compare a variety of labour market policies to determine the best way to compensate the groups that are harmed by liberalization. They distinguish two groups of losers: the movers (who bear the adjustment costs imposed on the economy by liberalization in terms of re-training and unemployment) and the stayers (those who remain trapped in the shrinking sector because they find it too difficult to acquire the skills required for the expanding sector, i.e. the exporting sector). They consider four policies to compensate movers: wage subsidies, training subsidies, employment subsidies and unemployment insurance. The authors explain that there are two distortions associated with each compensation scheme. The first comes from the policy itself since it distorts incentives. The need to pay for the compensation scheme creates the second distortion. They assume that any policy is financed by taxing earned income at

\footnotetext{
81 Janeba (2000).

82 Rodrik and van Ypersele (2001), Razin and Sadka (2004).
} 
a constant rate. In their setup the employment subsidy differs from a wage subsidy in that it is independent of the worker's wage so that all movers receive the same payment regardless of ability, i.e. both the employment and the training subsidies do not vary with ability, whereas both the wage subsidy and the unemployment benefit do. In the context of their model the authors argue that the optimal way to compensate the movers is with a targeted, temporary wage subsidy, and the optimal way to reach the stayers is with a targeted, temporary employment subsidy. They also find that the costs of compensating the stayers is much higher than the costs of compensating the movers, but that the total cost of compensation remains quite modest - it never rises above 5 per cent of the net benefit from liberalization.

Increases in wage inequality and, more generally, income inequality have been observed in numerous countries around the globe and have triggered calls for changes in redistribution policy. In the United States the discussion around redistribution policies has also been related to trade reform, possibly reflecting a concern among policymakers that rising inequality may make it increasingly difficult to introduce economic reforms, including trade reforms. ${ }^{83}$ Over the past 15 years, at first quietly and then with more momentum since 2000, wage insurance has emerged in the United States as a potential additional adjustment policy tool, particularly in the context of free trade (Kletzer, 2004). As proposed in Kletzer and Litan (2001), eligible workers would receive some fraction, perhaps half, of their weekly earnings loss. The fraction could vary by age and tenure of the worker. Payments begin only when a worker has a new (full-time) job

83 See, for instance, this quote from a speech by Federal Reserve Bank Chairman Ben Bernanke at the Federal Reserve Bank of Kansas City's Thirtieth Annual Economic Symposium (Jackson Hole, August 2006) : "The challenge for policymakers is to ensure that the benefits of global economic integration are sufficiently widely shared - for example, by helping displaced workers get the necessary training to take advantage of new opportunities-that a consensus for welfare - enhancing change can be obtained. Building such a consensus may be far from easy, at both the national and the global levels. However, the effort is well worth making, as the potential benefits of increased global economic integration are large indeed." 
and could continue for up to two years following the initial job loss, as long as the new job paid less than the old job. By "topping up" earnings if the new job pays less than the old, and only for a specified period, the programme offers re-employment incentives, in contrast to the incentives introduced by unemployment insurance and training subsidies. Taking into account these increased re-employment incentives, the programme can also be seen from an active labour market policy perspective, in the spirit of re-employment bonuses. ${ }^{84}$

To sum up, the debate on which level of redistribution to target and how to redistribute effectively in a globalized world is an ongoing one. Finding satisfactory answers does not appear to be straightforward and will be particularly challenging for developing countries that often lack any significant experience in this domain, and the necessary financial and administrative capacities. Yet, there are indications that the trade-off between equity and efficiency need not be steep and that win-win strategies exist where policies that are good for equity are also good for growth. ${ }^{85}$

\section{Education policies}

Education policies are likely to play an increasingly important role in modern economies. The reasons are manifold and include:

- Education policies can act as a redistribution tool in a world where the relative demand for skilled labour increases.

- Education levels determine countries' absorptive capacity, i.e. their capacities to adopt new technologies and maybe develop them

\footnotetext{
84 Re-employment bonuses are lump-sum payments to unemployed workers who find jobs within a specified limited timeframe.

85 See also Bigsten and Levin (2004) and Dağdeviren et al. (2004).
} 
further. Education levels thus determine to which extent countries can reap the benefits of innovation. ${ }^{86}$

- Education affects individuals' capacity to deal with change, an important aspect in a globalized world that expects individuals to constantly adapt to new situations.

- Education levels affect individuals' ability to be an active part in a global society. Globalization has, for instance, raised the requirements for effective communication in terms of linguistic skills, technological skills and skills to deal with different institutions and cultures.

The distributional impact of education policies has been analysed in Janeba (2000). He explores (theoretically) the role of government policies in a situation where the wage gap between the high and low-skilled is widening due to increasing foreign competition in the manufacturing sector of low-skilled intensive goods. Specifically, he tries to find the best way to deal with inequality in an open economy - whether scarce government resources should be used to encourage investment in education or to redistribute income in favour of those who remain unskilled. A linear income tax, for instance, tends to be progressive because of the uniform subsidy, thereby mitigating the increasing wage gap between low-skilled and high-skilled workers. Yet, at the same time, the policy reduces the incentive to become a skilled worker in the first place. By, contrast, when the government subsidizes investment in education, more people tend to become skilled workers. The downside of this policy seems to be that a regressive bias is built in because the existing tax money is used for those who in the end are better off anyway.

86 Keller (1996) argues that access to foreign technologies alone does not increase growth rates of developing countries and he shows that if a country's absorptive capacity (measured by its stock of human capital) remains unchanged, a switch to an outward orientation may not lead to a higher growth rate. 
There is an increasing awareness among economists that education policies are key to enabling economies to adjust to economic change and to take advantage of its opportunities. The idea that upgrading the skill level of countries' workforce is one answer to the challenges faced by modern economies has found wide acceptance for quite a while now. But many countries, both in the developed and in the developing world, appear to find it difficult to skill the low-skilled. Another impression that arises increasingly from the literature is that providing higher skills to more people is not enough.

McIntosh and Steedman (2001) analyse the change in demand for different skill levels in a number of European countries and propose policy responses. Their research focuses on France, Germany, the Netherlands, Portugal, Sweden and the United Kingdom and they observe that the supply of low-skilled individuals continues to exceed demand at the prevailing labour costs. They recommend that young people should be encouraged to reach at least an ISCED 3 (upper secondary) level. This will help with meeting future demands of the workplace since many unskilled jobs now require better communication and social skills. More generally, they recommend a balance between formal education and personal and social skills.

Tickly (2001) examines the evolution of educational systems in developing countries over the various phases of globalization. During the colonial period educational systems were limited to equipping indigenous labourers with basic skills required by the colonial economic and administrative systems - a policy that has been blamed for the marginalization of African economies. Tickly (2001) notes that education in Africa remains profoundly linked to the politics of the postcolonial state and would remain so in the foreseeable future while Europe and the newly industrialized countries of the Pacific Rim have 
gone through educational transformation. The paper argues that there is need for more information on the skills needed for development in the global era if education is to have a real, positive impact on development.

Also Ridell (1996) emphasizes the need for a different approach to education policies in modern integrated economies. While basic literacy was necessary, and maybe enough during previous waves of integration, he argues that recent waves of globalization require very different human resources in order for developing countries to compete. According to the author, this change in requirement for skills stems from a shift in trade patterns: a shifting reliance on the South for intermediate and finished products as opposed to primary materials in previous waves of globalization. Hence there is the need to adjust educational systems in the face of new production systems. His concept of "educating for employment" emphasizes the need for education to go beyond formal education and continue with on-the-job training/education. Hence, his suggested action plan for developing countries includes overcoming illiteracy by going on with policies that enhance primary and secondary education. In addition, policies enhancing flexibility in the labour force should be implemented. These should include the development of analytical/ logical skills, communication skills, interpersonal skills as well as openness to continual learning.

Economists have also emphasized the need for education systems in industrialized countries to be flexible enough to adjust to the changing demands for skilled labour. The issue has been raised in the context of the recent offshoring literature discussed earlier in this study. It has, in particular, been argued that it may in the future be more important for children to learn how to learn than to learn any particular set of skills, as they may have to adapt their skills continuously during 
their working life. ${ }^{87}$ As Blinder (2006) puts it: "Simply providing more education is probably a good thing on balance, especially if a more educated labour force is a flexible labour force, one that can cope more readily with non-routine tasks and occupational change. However education is far from a panacea ... . In the future, how children are educated may prove to be more important than how much."

It has been argued in the literature that market forces are unlikely to generate the supply of skills that matches the demand for skills. Instead, educational planning at government level appears to be required in order to avoid significant mismatches. Riddel (1996) recommends that educational planners should start from a framework of global development and should be more concerned with longerterm, dynamic issues rather than looking at the link between education and development in a static nation state. They should focus on creative alternatives that bridge new education with flexible production as well as bridging the gap between firms and communities.

\section{Other policy areas}

A number of other policy areas have been emphasized in the literature that are likely to have an impact on the employment response to trade liberalization. Although it is beyond the scope of this overview to discuss them in detail they are briefly introduced in this section.

(a) Supply response in developing countries

How successful developing economies are in the creation of more and/or better jobs, with attendant implications for poverty, depends

87 Baldwin (2006). 
above all on the supply response of the economy to trade liberalization and on the employment intensity of that supply response. The reduction of tariffs and other trade barriers lowers transaction costs and therefore makes trade more beneficial. But if other transaction costs are very high trade may still not be sufficiently beneficial. Traderelated transaction costs refer to a myriad of components, including: communication costs with clients, domestic transport costs to bring goods from the production site to the border, time and money spent in ports on border procedures or to make products ready for shipment, international transport costs and inspection and certification costs. Many of these costs are higher in developing countries than in industrialized countries and there are reasons to believe that they have in numerous cases been responsible for disappointing supply responses to economic reform in developing countries. ${ }^{88}$

The role of infrastructure has been emphasized in a number of studies analysing the determinants of trade flows. ${ }^{89}$ Estimating a gravity model of trade Nordås and Piermartini (2004) show that the quality of infrastructure has a significant and relatively large impact on bilateral trade flows, and among the individual infrastructure indicators, port efficiency has the largest impact on bilateral trade. Other studies confirm this. Clark et al. (2004) find that port efficiency is an important determinant of ocean freight costs. They estimate, for example, that maritime transport costs in Brazil or India would fall by over 15 per cent if their port efficiency was at the level of France or Sweden. Their findings also suggest that if a country like Peru or Turkey were to improve seaport efficiency to a level similar to Australia or Iceland, they would be able to increase trade by roughly 25 per cent. Limão and Venables (2001) find that own infrastructure

\footnotetext{
88 See also UNCTAD (2006b).

89 The importance of infrastructure is underlined by the before-mentioned study by Lopez (2004), who finds that improvements in infrastructure are likely to lead to both growth and progressive distributional change.
} 
explains 40 per cent of transport costs for coastal countries while own and transit country infrastructure explains 60 per cent of transport costs for landlocked countries.

These findings have important policy implications for leastdeveloped countries. If improvements in the quality of infrastructure in these countries lag behind the development in more developed countries, their share of world trade is likely to continue to decline. Worse, it appears that time to market and hence the quality of infrastructure matter more than before in sectors such as textiles and clothing; a development that threatens to undermine least-developed countries' comparative advantage in important segments of these sectors. Improvements in the quality of infrastructure can, however be costly and in the short term beyond the means of the governments of developing countries, in particular the least developed among them.

There appears to be an increasing awareness of the role the international community can play in helping developing countries to overcome supply constraints, that is reflected in the debate on aid for trade. There also appears to be a common understanding of the possible bottlenecks for supply response in developing countries. They include inadequate finance, physical infrastructure, telecommunication, information and human capital. But there does not seem to be a clear understanding of how to use aid for trade in order to overcome supply constraints..$^{90}$ Examples exist of countries that have successfully combined outward-orientation, sound macroeconomic policies and financial assistance, and lessons could be learned from these examples. ${ }^{91}$

\footnotetext{
90 See OECD (2006) for suggestions on "how to make aid for trade effective."

91 See, for instance, IMF (1997) on the progress of the Irish economy as a result of outward-oriented policies, financial discipline and EU assistance. The possible benefits of US assistance for capacity building in partner countries has also been raised in the context of CAFTA (see Salazar-Xirinachs and Granados, 2004).
} 
(b) The role of financial markets for efficiency and stability

Badly functioning financial markets can lead to significant supply constraints in developing countries. Where credits are allocated inefficiently, companies with export potential will not necessarily be able to obtain the funding required to expand their production or start new activities. ${ }^{92}$ Small companies more frequently suffer from credit constraints than larger entities, both in industrialized and developing countries. But in many developing countries, notably in Africa, the majority of business is done by small or very small firms. As a consequence, credit constraints for small companies can result in a significant adjustment burden for the economy as a whole.

An efficient financial sector is in many respects important for a country's development prospects, but unfortunately it is not something that can be introduced overnight. Companies have in many cases adapted to the prevailing situation and finance investment out of savings. In fact, in many developing countries new firms are almost entirely financed from the founder's own savings, as credit constraints tend to be particularly stringent for start-up finance.

In recent years, systems of microfinance institutions (MFIs) have developed outside the formal sector in many developing countries to offer financial services to a larger part of the population. For example, in Tanzania, only about 6 per cent of the population had access to the formal banking sector (4 per cent in rural areas) and the activities of MFls also reached around 6 per cent of the population in 2002. ${ }^{93}$ MFIs also play an important role in entrepreneurial activities in some

92 Bacchetta and Jansen (2003).

93 Basu et al. (2004). 
developing countries. In Tanzania, for instance, MFls held about 60 per cent and 11 per cent of total commercial bank deposits and credits, respectively. The appropriate integration of the microfinance sector into the regulatory system is therefore an important challenge for many developing countries.

Opening up the financial sector to foreign competition can contribute to increasing the sector's efficiency and expanding its activities. If accompanied by increased international capital flows, increased financial openness may, however, also have distributional consequences, as pointed out in Rama (2003). He contends that the main threat to workers comes from international capital movements and the financial crises they can prompt. These crises can lead to a durable decline in the labour share of income. If they can be avoided, the long-term wage gains from globalization should more than offset the short-term losses, even assuming a very high time preference. The potentially significant negative effects of financial liberalization on employment and income have also been emphasized in Van der Hoeven and Lübker (2006).

(c) The pace of trade liberalization

The design of trade policy may affect how the private sector reacts to trade reforms. By announcing trade reform for a certain date in the future, i.e. by allowing for implementation periods, governments give economic actors a warning about upcoming changes. Companies thus get a chance to accumulate profits and to rely on internal financing for adjustment to foreign competition. Unfortunately, the literature gives little guidance as to the appropriate length of such implementation periods. 
The possible role of adjustment periods has been analysed in Levy and van Wijnbergen (1995). They argued in favour of gradual trade liberalization together with a well-targeted adjustment programme in the case of agriculture liberalization in the context of NAFTA in Mexico. The adjustment programme they suggested was a programme of investments in land improvements in order to transform a factor that was to lose from trade reform (rain-fed land) into a factor that would gain from trade reform (irrigated land). The authors of the study argued that gradual trade liberalization would make it possible for the transformed factors to reap the combined benefits of transformation and trade without having to experience a period of losses.

The NAFTA agreement had provided for a transitional period of 15 years for the Mexican corn sector, but liberalization was accelerated and the 1995 crisis made it impossible to allocate fiscal resources to the transforming sector. According to one study (Nadal, 2000) corn production has remained stable in Mexico after trade reform, despite sharp drops in corn prices. In other words, trade reform does not seem to have induced the expected reallocation of resources. The same study argues that "the situation of rural farmers, especially corn producers, is desperate, partly as a result of the NAFTA-induced changes in trade and other government policies."

\section{F. CONCLUSIONS}

The material presented so far illustrates that there are no simple generalizations possible on the relationship between trade and employment. The standard trade model focusing on inter-sectoral trade among very different countries proves to be a rather inadequate guide. There is a growing literature pointing to the importance of new factors influencing the trade-employment relationship such as the impact of FDI, the nature of trade (e.g. different types of intra- 
industry trade among similar countries versus North-South trade), the role of technological change and the impact of greater openness on the elasticity of demand for labour. Differences in the initial conditions of countries, in the nature of institutions and in how trade policies are implemented also affect the relationship between trade and employment. It is important to understand the role of these new factors in forming an overall judgement on the relationship between trade and employment as well as in the formulation of policy. The review of the recent literature contained in the present study hopefully establishes this point. At the same time, it has also indicated areas where, in the light of this, the current state of knowledge is still limited and where further research could make a useful contribution to the formulation of better policies.

The review attempted in this study suggests that globalization can be good for most workers in both industrialized and developing countries, provided the appropriate economic policies are in place. But it may not be good for all workers, and its distributional implications should not be ignored. The overview indicates that the increase in the relative demand for skilled labour is a global phenomenon often resulting in increased skill premiums. Traditional trade theory would have predicted that trade between industrialized countries and developing countries leads to increased skill premiums in the industrialized world. But research has shown that this so-called NorthSouth trade can only explain a small part of the observed changes in relative wages. Trade among industrialized countries is also likely to play a role, but it is above all skill-biased technological change that appears to drive observed increases in the skill premium.

In the case of developing countries, the literature also points to the significance of new factors such as FDI and the relocation of production, skill-biased technical change, and the emergence of China 
as a major producer of labour-intensive manufactures, in explaining changes in wage inequality. Recent research also indicates that trade and outsourcing are connected phenomena that both stimulate the pace of technological change. To the extent that technological change enhances growth, this process should be encouraged. But the literature agrees that the process will increasingly shift relative demand for labour towards skilled labour.

Independent of their causes, increases in the skill premium, or even income inequality, represent a serious challenge for developing countries in which redistribution policies have traditionally been absent or inadequate. The literature does not provide an answer to the question of how to introduce appropriate policies in countries that often lack the necessary administrative and financial capacities. Further research in this area will clearly be useful to policymakers.

The discussion in this study on the links between trade reform on the one hand and labour and social policies on the other hand has also shown that there is no agreement on how to design appropriate redistribution policies in a globalizing world. Any redistribution policy changes incentives for those on the receiving end and thus carries the potential to introduce distortions to market processes. The need to pay for the redistribution policy, for instance through levying income or consumption taxes, creates an additional distortion. The design of effective redistribution schemes in a world where some production factors are more mobile at the global level than others thus also represents a serious challenge for relatively well-equipped governments in industrialized countries. New research focussed on this question would help policy-makers to meet their important challenge. 
Another policy tool that can have redistributive effects is education policy. Policies that provide wider access to education have also been identified in the literature as good pro-poor policies, as they stimulate growth and reduce inequality at the same time. The present study also emphasized the increasingly important role of education policies in determining how well countries cope with economic and technological change. At the same time, however, this study pointed out that it becomes increasingly hard to predict the set of skills needed for future employment and that education systems will therefore need to be increasingly flexible in order to respond to economic changes. It may also become increasingly important to teach how to study in order to enable workers to adapt to changes in the demand for skills. The practical implications of this, however, do not appear to be entirely clear and further research on the issue of economic change and education could be useful to provide guidance to those responsible for education policy.

Other policies accompanying trade liberalization, especially the absence or presence of pro-poor policies, have an important influence on the impact of trade on inequality and the level of poverty. In addition to the already-mentioned education policies, investment in infrastructure has been identified in the literature as a good candidate for pro-poor policies. The quality of infrastructure is also an important determinant of countries' supply response to trade liberalization. Investments in infrastructure thus have the potential to help the poor via multiple channels: they reduce inequality, have a direct positive impact on growth and an indirect positive impact on growth via their effect on trade flows.

On an issue that is important for many developing countries, namely the impact of trade liberalization on the informal economy, the theoretical literature points to the possibility of both positive 
and negative impacts. The net outcome depends on which of these predominate. The empirical evidence is however very limited and shows mixed results. Further research on this issue should therefore be a priority.

The pace of trade liberalization also influences outcomes. Gradual liberalization combined with well-targeted adjustment programmes are likely to lower adjustment costs and increase benefits. The need for trade adjustment programmes seems more pressing in developing countries than in industrialized countries, where existing social protection arrangements, e.g. in the form of unemployment benefits, take care of those affected by job loss. While the introduction of wideranging social protection schemes in developing countries is desirable, it may not be feasible in the short run. The introduction of adjustment programmes of limited duration, targeting those negatively affected by trade reform, may be an interesting alternative. Although numerous examples of adjustment programmes directed at regions or sectors exist in industrialized countries, our knowledge of the efficient design of such programmes in the context of developing countries is still incomplete and needs to be strengthened through further research.

Another theme that has been discussed in this study is the rising perception of insecurity among workers, as revealed in worker surveys. The theoretical literature confirms that trade, in particular if combined with FDI, has the potential to increase volatility in labour markets. Surprisingly, statistics on labour market reallocation do not reveal a systematic pattern of increased labour market volatility. Research on how to reconcile the conflicting evidence on workers' perceptions of insecurity on the one hand and labour market statistics on the other hand is ongoing. 
Notwithstanding the evidence from labour market statistics, economists tend to agree that modern economies need to constantly reallocate resources, including labour, from old to new products, from bad to good firms. At the same time, workers value security and insurance against major adverse professional events, job loss in particular. In response to this demand for insurance, economies have used different tools to provide a buffer against the most negative consequences of job loss. The discussion in this study has shown there are reasons to believe that a trade-off exists between efficiency and insurance, but that this trade-off does not need to be very steep if insurance policies are designed appropriately. Again, getting the policy mix right is a pressing issue and further research can support the attainment of this objective. This is above all the case in developing countries that face the additional challenge of channelling important numbers of workers in the informal economy as smoothly as possible into formal activities.

The main conclusion that emerges from this study is that trade policies and labour and social policies do interact and that greater policy coherence in the two domains can have significantly positive impacts on the growth effects of trade reforms and thus ultimately on their potential to improve the quality of jobs around the world. From this perspective, research directed at supporting the formulation of more effective and coherent policies would clearly have a high pay-off to the international community. 
REFERENCES 
Acemoglu, D. (2002) 'Technical Change, Inequality, and the Labor Market', Journal of Economic Literature 40(1): 7-72.

Agenor, P. and Aizenman, J. (1996) 'Trade Liberalization and Unemployment', Journal of International Trade and Economic Development 5(3): 265-286.

Anderson, K. and Martin, W. (2005) 'Agricultural Trade Reform and the Doha Development Agenda', Policy Research Working Paper 3607, Washington, DC: World Bank.

Attanasio, O., Goldberg, P. K. and Pavcnik, N. (2003) 'Trade Reforms and Wage Inequality in Colombia', NBER Working Paper 9830, Cambridge, MA: National Bureau of Economic Research.

Bacchetta, M. and Jansen, M. (2003) Adjusting to Trade Liberalization: The Role of Policy, Institutions and WTO Disciplines, Special Studies 7, Geneva: World Trade Organization.

Baldwin, R. (2006) 'Globalisation: the Great Unbundling(s)', Paper for the Finnish Prime Minister's Office, Economic Council of Finland as part of EU Presidency.

Baldwin, R.E. (2003) 'Openness and Growth: What is the Empirical Relationship?', NBER Working Paper 9578, Cambridge, MA: National Bureau of Economic Research.

Barro, R. J. (2000) 'Inequality, Growth and Investment', NBER Working Paper 7038, Cambridge, MA: National Bureau of Economic Research.

Basu, A., Blavy, R. and Yulek, M. (2004) 'Microfinance in Africa: Experience and Lessons from Selected African Countries', IMF Working Paper 04/174, Washington, DC: International Monetary Fund.

Behrman, J. R., Birdsall, N. and Szekely, M. (2001) 'Economic Policy and Wage Differentials in Latin America' PIER Working Paper 01-048, Penn Institute for Economic Research, University of Pennsylvania.

Bentivogli, C. and Pagano, P. (1999) 'Trade, Job Destruction and Job Creation in European Manufacturing', Open Economies Review 10(2): 165-184.

Berman, E., Bound, J. and Griliches, Z. (1994) 'Changes in the Demand for Skilled Labor within US Manufacturing: Evidence from the Annual Survey of Manufacturers', Quarterly Journal of Economics 109(2): 367-397.

Bernard, A. and Jensen, J. (1999) 'Exceptional Exporter Performance: Cause, Effect or Both', Journal of International Economics 47(1): 1-38. 
--- (2004) 'Exporting and Productivity in the USA', Oxford Review of Economic Policy 20(3): 343-357.

Bernard, A. B., Redding, S. J. and Schott, P. K. (forthcoming) 'Comparative Advantage and Heterogeneous Firms', Review of Economic Studies.

Besley, T., Griffith, R. and Klemm, A. (2001) 'Empirical Evidence on Fiscal Interdependence in OECD Countries', LSE Working Paper, London: London School of Economics.

Bhagwati, J. (2000) The Wind of the Hundred Days: How Washington Mismanaged Globalization, Cambridge, MA: MIT Press.

Bigsten, A. and Levin, J. (2004) 'Growth, Income Distribution, and Poverty: A Review' in A. Shorrocks and R. van der Hoeven (eds.) Growth, Inequality and Poverty, Oxford: Oxford University Press.

Blanchard, O. (2005) 'European Unemployment: the Evolution of Facts and Ideas', NBER Working Paper 11750, Cambridge, MA: National Bureau of Economic Research.

Blinder, A. S. (2006) 'Offshoring: The Next Industrial Revolution?', Foreign Affairs 85(2): 113-128.

Boix, C. (2002) 'Globalization and the Egalitarian Backlash: Protection Versus Compensatory Free Trade', Paper prepared for the Workshop on 'Globalization and Egalitarian Redistribution', Santa Fe Institute.

Bolaky, B. and Freund, C. (2004) 'Trade, Regulation and Growth', Policy Research Working Paper 3255, Washington, DC: World Bank.

Bouët, A., Bureau, J.C., Decreux, Y. and Jean, S. (2005) 'Multilateral Agricultural Trade Liberalization: The Contrasting Fortunes of Developing Countries in the Doha Round', The World Economy 28(9): 1329-1354.

Brecher, R. and Choudhri, E. (1994) 'Pareto Gains from Trade, Reconsidered: Compensating for Jobs Lost', Journal of International Economics 36(3-4): 223-238.

Brecher, R. A. (1974) 'Minimum Wage Rates and the Pure Theory of International Trade', The Quarterly Journal of Economics, 88(1): 98-116.

Burgoon, B. (2001) 'Globalization and Welfare Compensation: Disentangling the Ties that Bind', International Organization 55(3): 509-551. 
Caballero, R. J., Cowan, K. N., Engel, E. M. R. A., and Micco, A. (2004) 'Effective Labor Regulation and Microeconomic Flexibility', NBER Working Paper 10744, Cambridge, MA: National Bureau of Economic Research.

Carr, M. and Chen, M. A. (2002) 'Globalization and the Informal Economy: How Global Trade and Investment Impact on the Working Poor', Employment Sector Working Paper on the Informal Economy, 2002/01, International Labour Office.

Charmes, J. (1998) 'Progress in Measurement of the Informal Sector: Employment and Share of GDP' in Handbook of National Accounting. Household Accounting: Experiences in the Use of Concepts and Their Compilation. Volume I: Household Sector Accounts, New York: UN Statistics Division.

Clark, X., Dollar, D. and Micco, A. (2004) 'Port Efficiency, Maritime Transport Costs and Bilateral Trade', NBER Working Paper 10353, Cambridge, MA: National Bureau of Economic Research.

Cline, W. R. (1997) Trade and Income Distribution, Washington, DC: Institute for International Economics.

Collier, P. (1993) 'Higgledy-piggledy Liberalization', The World Economy 16(4): 503512.

Comin, D. and Philippon, T. (2005) 'The Rise in Firm-Level Volatility: Causes and Consequences' in M. Gertler and K. Rogoff (eds.) NBER Macroeconomics Annual 2005, Vol. 20, Cambridge, MA: MIT Press .

Cox Edwards, A. and Edwards, S. (1996) 'Trade Liberalization and Unemployment: Policy Issues and Evidence from Chile', Cuadernos de Economía, Año 33, 99: 227250.

Currie, J. and Harrison, A. (1997) 'Trade Reform and Labor Market Adjustment in Morocco', Journal of Labor Economics 15(3): S44-S72.

Dağdeviren, H., van der Hoeven, R. and Weeks, J. (2004) 'Redistribution does Matter: Growth and Redistribution for Poverty Reduction' in A. Shorrocks and R. van der Hoeven (eds.) Growth, Inequality and Poverty, Oxford: Oxford University Press.

Davidson, C. and Matusz, S. (forthcoming) 'Trade Liberalization and Compensation', Review of International Economics.

Davidson, C., Martin, L. and Matusz, S. (1999) 'Trade and Search Generated Unemployment', Journal of International Economics 48: 271-299. 
Davis, S., Haltiwanger, J. and Schuh, S. (1996) Job Creation and Job Destruction, Cambridge, MA: MIT Press.

Decreux, Y. and Fontagné, L. (2006) 'A Quantitative Assessment of the Outcome of the Doha Development Agenda', CEPII Working Paper 10, Paris: Centre d'études prospectives et d'informations internationales.

Desai, M. (1999) 'Are We Racing to the Bottom? Evidence on the Dynamics of International Tax Competition' in Proceedings of the 915t Annual Conference on Taxation, Washington, DC: National Tax Association.

Dew-Becker, I. and Gordon, R. J. (2005) 'Where Did the Productivity Growth Go? Inflation Dynamics and the Distribution of Income', NBER Working Paper 11842, Cambridge, MA: National Bureau of Economic Research .

Dixit, A. and Norman, V. (1980) Theory of International Trade, Cambridge: Cambridge University Press.

---(1986) 'Gains from Trade without Lump-Sum Compensation', Journal of International Economics 36: 201-222.

Dollar, D. (1992) 'Outward-oriented Developing Economies Really Do Grow More Rapidly: Evidence from 95 LDCs, 1976-85', Economic Development and Cultural Change 40(3): 523-44.

--- and Collier, P. (2001) Globalization, Growth and Poverty: Building an Inclusive World, New York: Oxford University Press, for The World Bank.

Dollar, D. and Kraay, A. (2004) 'Trade, Growth and Poverty', Economic Journal 114(493): 22-49.

Duranton, G. (1999) 'Globalization, Productive Systems, and Inequalities', Paper presented at CEPR/CESPRI workshop on 'International Trade and Wage Inequality: Theory and Measurement' in Milan, October 1999.

Edwards, S. (1997) 'Trade Policy, Growth and Income Inequality', American Economic Review, Papers and Proceedings 87(2): 205-210.

Ethier, W. J. (2005) 'Globalization, globalisation: Trade, technology and wages', International Review of Economics and Finance 14(3): 237-258.

Fajnzylber, P. and Maloney, W. F. (2005) 'Labor Demand and Reform in Latin America', Journal of International Economics 66: 423-446. 
Falvey, R., Greenaway, D. and Silva, J. (2006) 'Trade, Human Capital and Labour Market Adjustment', Leverhulme Centre Research Paper 2006/03, Nottingham: Leverhulme Centre on Globalisation and Economic Policy.

Feenstra, R. C. and Hanson, G. H. (1997) 'Foreign Direct Investment and Relative Wages: Evidence from Mexico's Maquiladoras', Journal of International Economics 42(3-4): 371-393.

--- (2004) 'Global Production and Inequality: A Survey of Trade and Wages', in J. Harrigan (ed.) Handbook of International Economics, Oxford: Basil Blackwell.

Feenstra, R. and Lewis, T. (1994) 'Trade Adjustment Assistance and Pareto Gains from Trade', Journal of International Economics 36: 201-222.

Forteza, A. and Rama, M. (2001)'Labor Market"Rigidity" and the Success of Economic Reforms Across more than Hundred Countries', World Bank Working Paper 2521, Washington, DC: World Bank.

Fu, X. and Balasubramanyam, V.N. (2005) 'Exports, Foreign Direct Investment and Employment: The Case of China', World Economy, 28(4): 607-625.

Gaston, N. and Nelson, D. (2000) 'Globalization and Wages in OECD Economies: Linking Theory with Evidence' in J. Francois, D. Roland-Holst and D. van der Mensbrugghe (eds.) Globalization and Employment Patterns: Policy, Theory and Evidence, Oxford: Oxford University Press.

Gaston, N. and Trefler, D. (1997) 'The Labour Market Consequences of the CanadaUS Free Trade Agreement', Canadian Journal of Economics 30(1): 18-41.

Goh, C. and Javorcik, B. S. (2004) 'Trade Protection and Industry Wage Structure in Poland', NBER Working Paper 11143, Cambridge, MA: National Bureau of Economic Research.

Ghose, A. K. (2003) Jobs and Incomes in a Globalizing World, Geneva: International Labour Office.

Goldberg, P. K. and Pavcnik, N. (2004) 'Trade, Inequality and Poverty: What Do We Know? Evidence from Recent Trade Liberalization Episodes in Developing Countries', NBER Working Paper 10593, Cambridge, MA: National Bureau of Economic Research.

--- (2003) 'The Response of the Informal Sector to Trade Liberalization', CEPR Discussion Paper 3874, London: Centre for Economic Policy Research. 
Gourinchas, P.-O. (1999) 'Exchange Rates do Matter: French Job Reallocation and Exchange Rate Turbulence, 1984-1992', European Economic Review 43: 1279-1316.

Greenaway, D. (1993) 'Liberalizing Foreign Trade through Rose-Tinted Glasses', Economic Journal 103: 208-223.

Griffith, R., Harrison, R. and Macartney, G. (2006) 'Product Market Reforms, Labour Market Institutions and Unemployment', CEPR Discussion Paper 5599, London: Centre for Economic Policy Research.

Grossman, G. and Rossi-Hansberg, E. (2006) 'The Rise of Offshoring: It's Not Wine for Cloth Anymore', Paper presented at the Kansas City Federal Reserve Bank Symposium on 'The New Economic Geography: Effects and Policy Implications', Jackson Hole, WY, 24-26 Aug. 2006, http://www.kc.frb.org.

Hanson, G. and Harrison, A. (1999) 'Who Gains from Trade Reform? Some Remaining Puzzles', NBER Working Paper 6915, Cambridge, MA: National Bureau of Economic Research.

Harrison, A. (1996) 'Openness and Growth: A Time-Series, Cross-Country Analysis for Developing Countries', Journal of Development Economics 48(2): 419-447.

--- and Revenga, A. (1995) 'Factor Markets and Trade Policy Reform', World Bank Manuscript as cited in Matusz and Tarr (1999).

Hasan, R., Mitra, D. and Ramaswamy, K.V. (2003) 'Trade Reforms, Labor Regulations and Labor-Demand Elasticities: Empirical Evidence from India', NBER Working Paper 9879, Cambridge, MA: National Bureau of Economic Research.

Haskel, J. E. and Slaughter, M. (2003) 'Have Falling Tariffs and Transportation Costs Raised U.S. Wage Inequality?', Review of International Economics 11(4): 630-650.

Hayes, J., Ehrlich, S. and Peinhardt, C. (2002) ‘Globalization, the Size of Government, and Labor Market Institutions: Maintaining Support for Openness Among Workers'. Paper presented at the 2002 Annual Meeting of the Midwest Political Science Association, Chicago, 25-28 April 2002.

Heitger, B. and Stehn, J. (2003) 'Trade, Technical Change and Labour Market Adjustment', World Economy 26(10): 1481-1501.

Helpman, E., Melitz, M. J. and Yeaple, S. R. (2003) 'Exports versus FDI with Heterogeneous Firms', American Economic Review, 94(1): 300-316.

Hoekman, B. and Winters, A. (2005) 'Trade and Employment: Stylized Facts and Research Findings', Policy Research Working Paper 3676, Washington, DC: World Bank. 
ILO (2006) Global Employment Trends, Geneva: International Labour Office, http:// www.ilo.org/public.english/ employment/strat/stratprod.htm.

IMF (1997) 'IMF Concludes Article IV Consultation with Ireland', Press Information Notice 97/14, released July 25, 1997.

Janeba, E. (2000) 'Trade, Income and Government Policies', NBER Working Paper 7485, Cambridge, MA: National Bureau of Economic Research.

Jansen, M. (2003) 'International Trade and the Position of European Low-skilled Labour' in J. Addison and P. Welfens (eds.): Labour Markets and Social Security: Issues and Policy Options in the U.S. and Europe, Dordrecht: Springer.

--- and Turrini, A. (2004) 'Job Creation, Job Destruction, and the International Division of Labor', Review of International Economics 12(3): 476-494.

Johnson, G. and Layard, R. (1986) 'The Natural Rate of Unemployment: Explanation and Policy' in O. Ashenfelter and R. Layard (eds.) Handbook of Labour Economics, Volume II: 921-999, Amsterdam: North Holland.

Kapoor, R. (2005) 'The Impact of Globalization on the Informal Economy', mimeo, Geneva: International Labour Office.

Keller,W. (1996)'Absorptive Capacity: On the Creation and Acquisition of Technology in Development', Journal of Development Economics 49(1): 199-227.

Klein, M. W., Schuh, S. and Tries, R. K. (2003) 'Job Creation, Job Destruction and the Real Exchange Rate', Journal of International Economics 59(2): 239-265.

Kletzer, L. (2004) 'Trade-related Job Loss and Wage Insurance: a Synthetic Review', Review of International Economics 12(5): 724-748.

--- and Litan, R. E. (2001) 'A Prescription to Relieve Worker Anxiety', Policy Brief PB01-2, Washington, DC: Peterson Institute for International Economics.

Kucera, D. and Sarna, R. (2006) 'Trade Union Rights, Democracy, and Exports: A Gravity Model Approach', Review of International Economics 14(5): 859-882.

Lawrence, R. and Slaughter, M. (1993) 'Trade and US Wages: Giant Sucking Sounds or Small Hiccup?', Brookings Papers on Economic Activity 2: 161-210.

Lee, E. (2005) 'Trade Liberalization and Employment', DESA Working Paper 5, New York, NY: UN Department of Economic and Social Affairs.

Lee, H. Y., Ricci, L. A. and Rigobon, R. (2004) 'Once Again, Is Openness Good for Growth?', Journal of Development Economics 75(2): 451-472. 
Levy, S. and van Wijnbergen, S. (1995) 'Transition Problems in Economic Reform: Agriculture in the North American Free Trade Agreement', The American Economic Review, 85(4): 738-754.

Limão, N. and Venables, A. J. (2001) 'Infrastructure, Geographical Disadvantage, Transport Costs and Trade', World Bank Economic Review 15(3): 451-479.

Ljunqvist, L. and Sargent, T. (1998) 'The European Unemployment Dilemma', Journal of Political Economy 106(3): 514-550.

---(2005) Jobs and Unemployment in Macroeconomic Theory: A Turbulence Laboratory, mimeo, New York, NY: New York University.

Lopez, J. H. (2004) 'Pro-growth, pro-poor: Is there a trade-off?', Policy Research Working Paper 3378, Washington, DC: World Bank.

Loayza, N., Fajnzylber, P. and Calderón, C. (2005) 'Economic Growth in Latin America: Stylized Facts, Explanations, Forecasts' in World Bank Latin American and Caribbean Studies, Washington, DC: World Bank.

Lundberg, M. and Squire, L. (2003) 'The Simultaneous Evolution of Growth and Inequality', The Economic Journal 113(487): 326-344.

Manasse, P. and Turrini, A. (2001) 'Trade, Wages and "Superstars", Journal of International Economics 54(1): 97-117.

Marjit, S. and Maiti, D. S. (2005) 'Globalization, Reform and the Informal Sector', Expert Group on Development Issues, United Nations University - WIDER, Helsinki, Finland.

Matusz, S. J. (1996) 'International Trade, the Division of Labor and Unemployment', International Economic Review 37(1): 71-85.

--- and Tarr, D. (1999) 'Adjusting to Trade Policy Reform', World Bank Working Paper 2142, Washington, DC: World Bank.

McIntosh, S. and Steedman, H. (2001) 'Low Skills: A Problem for Europe', Centre for Economic Performance, London School of Economics for the European Commission on the NEWSKILLS Programme of Research.

Melitz, M. J. (2003) 'The Impact of Trade on Intra-Industry Reallocations and Aggregate Industry Productivity', Econometrica 71(6): 1695-1725.

Milner, C. and Wright, P. (1998) 'Modelling Labour Market Adjustment to Trade Liberalisation in an Industrialising Economy', The Economic Journal, 108(447): 509528. 
Mussa, M. (1978) 'Dynamic Adjustment in the Heckscher-Ohlin-Samuelson Model', Journal of Political Economy 86(5): 775-791.

Nadal, A. (2000) 'The Environmental and Social Impacts of Economic Liberalization on Corn Production in Mexico,' Study commissioned by Oxfam, UK, and WWF International.

Neumayer, E. and de Soysa, I. (2006) 'Globalization and the Right to Free Association and Collective Bargaining: An Empirical Analysis', World Development 34(1): 31-49.

Nicita, A. (2006) 'Export-Led-Growth, Pro-Poor or Not? A Case Study of Madagascar's Textile and Apparel Industry', Policy Research Working Paper 3841, Washington, DC: World Bank.

Nordås, H. K. and Piermartini, R. (2004) 'Infrastructure and Trade', Staff Working Paper ERSD-2004-04, Geneva: World Trade Organization.

OECD (2005) OECD Employment Outlook 2005, Paris: Organisation for Economic Cooperation and Development.

--- (2006) Aid for Trade: Making It Effective, Paris: Organisation for Economic Cooperation and Development.

Papageorgiou, D., Choksi, A. and Michaely, M. (1990) Liberalizing Foreign Trade in Developing Countries: The Lessons of Experience, Washington, DC: World Bank.

Piermartini, R. and Teh, R. (2005) 'Demystifying Modelling Methods for Trade Policy', WTO Discussion Paper 10, Geneva: World Trade Organization.

Polaski, S. (2006) Winners and Losers: Impact of the Doha Development Round on Developing Countries, Washington, DC: Carnegie Endowment for International Peace.

Rama, M. (1994) 'The labor market and trade reform in manufacturing' in M. Connolly. and J. de Melo (eds.): Effects of Protectionism on a Small Country: The Case of Uruguay, Washington, DC: World Bank.

--- (1999) 'Public Sector Downsizing: An Introduction', The World Bank Economic Review 13(1): 89-116.

--- (2003) 'Globalization and Workers in Developing Countries', Policy Research Working Paper 2958, Washington, DC: World Bank.

Razin, A. and Sadka, E. (2004) 'Capital Income Taxation in the Globalized World', NBER Working Paper 10630, Cambridge, MA: National Bureau of Economic Research. 
Revenga, A. (1995) 'Employment and Wage Effects of Trade Liberalization: The Case of Mexican Manufacturing', Policy Research Working Paper 1524, Washington, DC: World Bank.

Riddell, A. R. (1996) 'Globalization: Emasculation or Opportunity for Educational Planning?', World Development 24(8): 1357-1372.

Robbins, D. J. (1996) 'HOS Hits Facts: Facts Win; Evidence on Trade and Wages in the Developing World', Development Discussion Paper 557, Cambridge, MA: Harvard Institute for International Development, Harvard University.

Robinson, J. A. (2000) 'Where Does Inequality Come From? Ideas and Implications for Latin America', Paper prepared for the OECD Conference on 'Poverty and Income Inequality in Developing Countries: A Policy Dialogue on the Effects of Globalization', Paris, 30 Nov.-1 Dec. 2000.

Rodríguez, F. and Rodrik, D. (2001) 'Trade Policy and Economic Growth: A Skeptics Guide to Cross-National Evidence', in B. Bernanke and K. Rogoff (eds.), NBER Macroeconomics Annual 2000 15, Cambridge, MA: MIT Press.

Rodrik, D. (1997) Has Globalization Gone too Far?, Washington, DC: Institute for International Economics.

Rodrik, D. and van Ypersele, T. (2001) 'Capital Mobility, Distributive Conflict and International Tax Coordination', Journal of International Economics 54(1): 57-73.

Rogoff, K. (2005) ‘Hollywood's Favourite Villains', Project Syndicate.

Sachs, J. and Warner, A. (1995) 'Economic Reform and the Process of Global Integration', Brookings Papers on Economic Activity 1: 1-118.

Salazar-Xirinachs J. M. and Granados J. (2004) 'The US-Central America Free Trade Agreement: Opportunities and Challenges' in J. Schott (ed.) Free Trade Agreements: US Strategies and Priorities, Washington, DC: Institute of International Economics.

Sanchez-Paramo, C. and Schady, N. (2003) 'Off and Running? Technology, Trade, and the Rising Demand for Skilled Workers in Latin America', Policy Research Working Paper 3015, Washington, DC: World Bank.

Sapir, A. (2006) 'Globalization and the Reform of European Social Models', Journal of Common Market Studies 44(2): 369-90.

Scheve, K. and Slaughter, M. J. (2004) 'Economic Insecurity and the Globalization of Production', American Journal of Political Science 48(4): 662-674. 
Slaughter, M. J. (1998) 'International Trade and Labor-Market Outcomes: Results, Questions, and Policy Options', The Economic Journal 108(450): 1452-1462.

--- (2000) 'Trade and Labor-Market Outcomes: What about Developing Countries?', Paper prepared for NBER Inter-American Seminar on Economics.

--- (2001) 'International Trade and Labor-Demand Elasticities', Journal of International Economics 54(1): 27-56.

--- (forthcoming) 'Globalization and Declining Unionization in the United States', Industrial Relations.

Soares, F. V. (2005) 'The Impact Of Trade Liberalization On The Informal Sector In Brazil', International Poverty Centre, UNDP Working Paper 7, New York, NY: United Nations Development Programme .

Spector, D. (2001) 'Is it possible to redistribute the gains from trade using income taxation?', Journal of International Economics 55(2): 441-460.

--- (2004) 'Competition and the Capital-Labor Conflict', European Economic Review 48(1): 25-38.

Spilimbergo, A., Londoño, J.L. and Székely, M. (1999) 'Income Distribution, Factor Endowments, and Trade Openness', Journal of Development Economics 59(1): 77101.

Tikly, L. (2001) 'Globalization and Education in the Postcolonial World: Towards a Conceptual Framework', Comparative Education 37(2):151-171.

Trefler, D. (2001) 'The Long and Short of the Canada-US Free Trade Agreement', NBER Working Paper 8293, Cambridge, MA: National Bureau of Economic Research.

UNCTAD (2005) World Investment Report, Geneva: United Nations Conference on Trade and Development.

--- (2006a) 'Data Show Foreign Direct Investment Climbed Sharply in 2005', Press release UNCTAD/PRESS/PR/2006/002, released 23 Jan. 2006.

---(2006b) Least Developing Countries Report 2006: Developing Productive Capacities, Geneva: United Nations Conference on Trade and Development.

Van der Hoeven, R. and Lübker, M. (2006) 'External Openness and Employment: The Need for Coherent International and National Policies', Paper prepared for the Development Forum on Productive Employment and Decent Work, United Nations Department of Economic and Social Affairs, ECOSOC Chamber, 8-9 May 2006. 
Van Welsum, D. and Reif, X. (2005) 'Potential Offshoring: Evidence from Selected OECD Countries,' in L. Brainard and S. M. Collins (eds) Brookings Trade Forum 2005, Washington, DC: The Brookings Institution.

Van Welsum, D. and Vickory, G. (2006) 'The Share of Employment Potentially Affected by Offshoring - An Empirical Investigation', Report of the OECD Working Party on the Information Economy DSTI/ICCP/IE(2005)8, Paris: OECD.

Wacziarg, R. and Wallack, S. J. (2004) 'Trade Liberalization and Intersectoral Labor Movements', Journal of International Economics 64(2): 411-439.

--- and Welch, K. H. (2003) 'Trade Liberalization and Growth: New Evidence', NBER Working Paper 10152, Cambridge, MA: National Bureau of Economic Research.

Wei, S. and Wu, Y. (2001) 'Globalization and Inequality: Evidence from Within China', NBER Working Paper 8611, Cambridge, MA: National Bureau of Economic Research.

Winters, A. (2000) 'Trade and Poverty: Is There a Connection?' in D. Ben-David, H. Nordström and A. Winters: Trade, Income Disparity and Poverty, Special Studies 5, Geneva: World Trade Organization.

Woo, W. T. and Ren, R. (2002) 'Employment, Wages and Income Inequality in the Internationalization of China's Economy', Employment Paper 2002/39, Geneva: International Labour Office.

Wood, A. (1994) North-South Trade, Employment and Inequality: Changing Fortunes in a Skill-Driven World, Oxford: Clarendon Press.

--- (1997) 'Openness and Wage Inequality in Developing Countries: The Latin American Challenge to East Asian Conventional Wisdom', The World Bank Economic Review 11(1): 33-58.

World Commission on the Social Dimension of Globalization (2004) A Fair Globalization: Creating Opportunities for All, Geneva: International Labour Office.

WTO (2006) International Trade Statistics 2006, Geneva: World Trade Organization.

Zhu, S. C. and Trefler, D. (2005) 'Trade and Inequality in Developing Countries: A General Equilibrium Analysis', Journal of International Economics 65(1): 21-48. 
